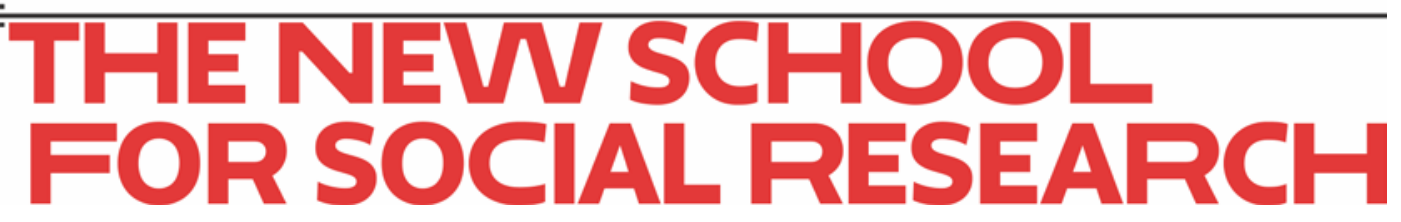

Cédric Durand and William Milberg

\title{
Intellectual Monopoly in Global Value Chains
}

July 2018

Working Paper 07/2018

Department of Economics

The New School for Social Research 


\title{
Intellectual Monopoly in Global Value Chains
}

July 2018

Cédric Durand (CEPN/Paris13)

William Milberg (New School for Social Research, NY)

\section{JEL codes}

D43 - F13 - F23 -F63

\section{Key words}

Global Value Chains, Intellectual Property Rights, Intangible Assets

\begin{abstract}
More than two decades of scholarship on global value chains (GVCs) has reshaped our understanding of the global economy while tracking the international fragmentation of productive process and its socioeconomic consequences. In this paper we focus on the effort by lead firms to capture market power in the provision of and production of intangible assets. The analysis builds on Pagano's (2014) notion of "intellectual monopoly", where government protections of intellectual property have the effect of locking in the monopoly power from intangible asset creation. We extend it to the presence of scale economies and network externalities associated with the production of intangible assets.
\end{abstract}




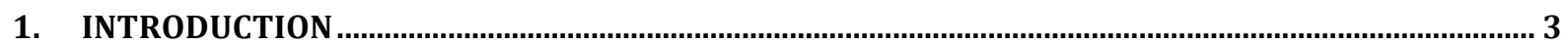

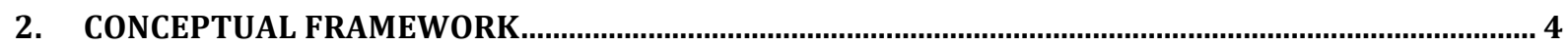

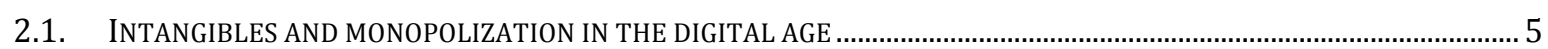

2.2. INTANGIBLES AND COORDINATION OF GLOBAL VALUE CHAINS ……....................................................................

2.3. ENDOGENOUS ASYMMETRIES OF MARKET STRUCTURES WITH INTANGIBLES ............................................................. 8

3. THE SIMULTANEOUS EXPANSION OF INTELLECTUAL PROPERTY RIGHTS AND GLOBAL VALUE

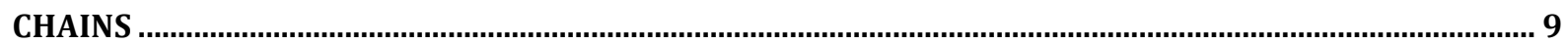

3.1. THE INTERNATIONALIZATION OF IP REGULATION THROUGH TRADE AGREEMENTS..................................................11

3.2. HISTORICAL AND THEORETICAL PERSPECTIVES ON IP REGULATION AND DEVELOPMENT .......................................18

3.3. THE COMPLEMENTARITY BETWEEN GVC TRADE AND IPRS .................................................................................2

4. MONOPOLIZATION DYNAMICS ARISING FROM NETWORK COMPLEMENTARITIES AND

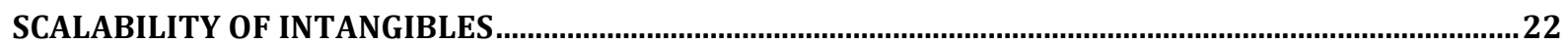

4.1. GATE-KEEPING AND NATURAL MONOPOLY FORCES ARISING FROM CHAIN INTEGRATION.......................................23

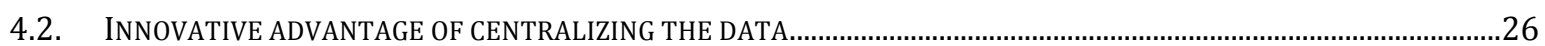

4.3. UNEVEN INTANGIBLE INTENSITY AND THE UNEVEN DISTRIBUTION OF RETURNS TO SCALE ...................................29

5. INTELLECTUAL MONOPOLY, ECONOMIC GROWTH AND DEVELOPMENT …..................................... 32

5.1. UNEVEN GEOGRAPHICAL DISTRIBUTION OF INTANGIBLES ................................................................................

5.2. FINANCIALIZATION AND STAGNATION TENDENCIES WITH INTELLECTUAL MONOPOLY ...........................................34

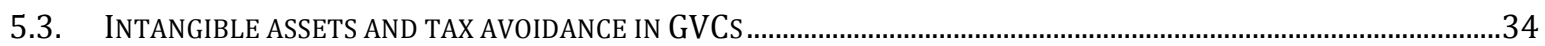

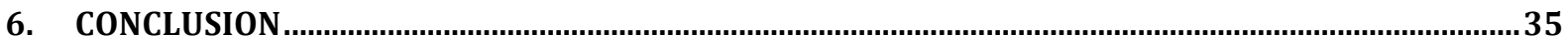

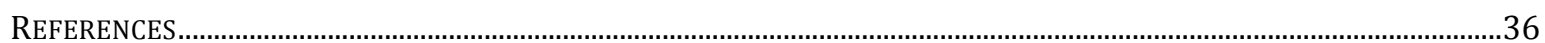




\section{Introduction}

More than two decades of scholarship on global value chains (GVCs) has reshaped our understanding of the global economy while tracking the international fragmentation of productive process and its socioeconomic consequences for both developing and developed countries (Bair, 2009; Gereffi et al., 2005; Milberg and Winckler, 2013; Taglioni and Winkler, 2016; Timmer et al., 2014).

Global value chain analysis has largely focused on production of tangible goods. And the great expansion of GVCs -- a driving force of globalization -- is often attributed to the drop in value added from fabrication and assembly and the relative rise in value added coming from pre- and post-fabrication activites, including design, R\&D, marketing, finance and after-sales service. The general picture is captured in the commonly-used smiling curve, and presented in Figure 1. The shift from the relatively flat smile curve across the full process of producing value in the "1970s", to a steep one in the more recent period, is attributed to the massive rise of productive capacity globally and the lowering of the cost of managing such global production.

Figure 1: The smile curve, 1970s vs. 21 ${ }^{\text {st }}$ century (Authors' elaboration based on Shih, 1996)

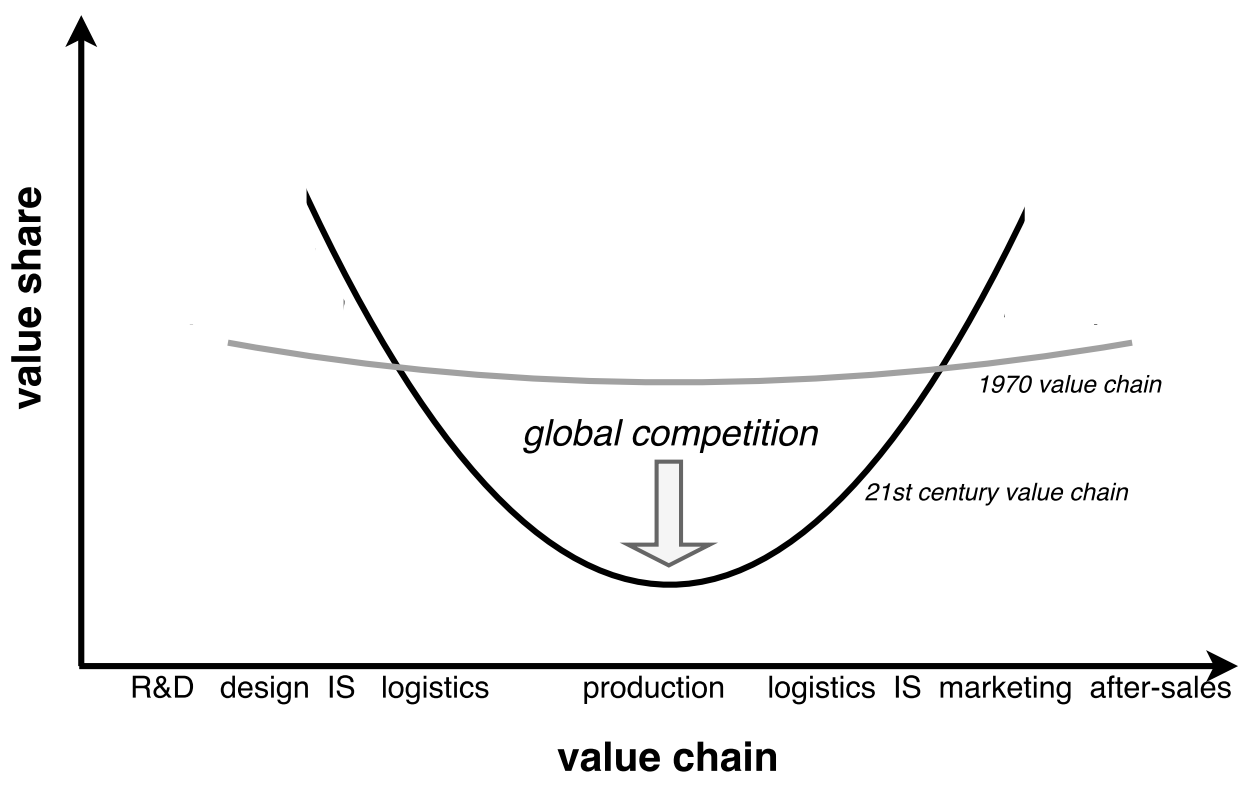

Much attention has been given to how GVCs involve the expansion of low-cost supplier networks, in which value added is low. This is seen as the dip in the middle of the smile curve as shown in the Figure. Less attention has been paid to the effort by lead firms to raise the value added in the non-fabrication and assembly parts of the production 
process and even to specialize in services which do not require such a dip in the middle of the curve.

In this paper we focus specifically on the effort by lead firms to capture market power in the provision of and production of intangible assets. The analysis builds on Pagano's (2014) notion of "intellectual monopoly", where government protections of intellectual property have the effect of locking in the monopoly power from intangible asset creation. We extend it to "information rents" (Foley, 2013) arising from the presence of scale economies and network externalities associated with the production of intangible assets.

Network externalities and scale economies are international in scope, so it is important to put the analysis of intellectual monopoly within the context of international trade and international trade agreements. The GVC framework, with its emphasis on market structures and the international distribution of value added, is particularly well-suited for studying the impact of IPRs and intangibles related network dynamics.

Our analysis is illustrated by numerous cases provided by the business and academic literature and informed by original stylized facts elaborated using Compustat, World Input Output (WIOT) and Design of Trade Agreements (DESTA) Databases in addition to information available from international organizations.

The second section introduces and contextualizes the concepts of intangibles and intellectual monopoly and presents the hypothesis of endogenous asymmetries of market structure in GVCs with intangibles. The third section shows the parallel expansion of intellectual property rights and GVC trade. Trade agreements are no longer mainly about traditional trade restrictions but aim at deeper integration between countries through regulatory standards convergence (Rodrik, 2018), in particular intellectual property matters, which we show are closely related to the expansion of GVCs. The fourth section explains the role of network complementarities and scalability of intangibles in fostering monopolization dynamics in GVCs. The fifth section discusses the implications of our analysis for development prospects in developing and high income economies. Section 6 concludes.

\section{Conceptual framework}

Within the GVC literature, numerous works have examined some aspect of the rising importance of knowledge management and intangible assets, including the interaction between innovation systems and GVCs (Lee and Malerba, 2017; Pietrobelli and Rabellotti, 2011), and the limitations of knowledge transfers between multinational corporations (MNCs) and local suppliers in developing economies (Saliola and Zanfei, 2009). Case studies have observed that the capture of value added is largely detached 
from the flow of physical goods and mainly related to intangible aspects of the supply chain, in particular in the case of smartphones (Ali-Yrkkö et al., 2011; Kraemer et al., 2011, Sturgeon, 2013). Heintz (2006) builds a theoretical model of oligopoly rents from branding and implications for economic development. Recent empirical work on intangibles and GVCs at the industry level indicates that the share of intangibles in the value of final products has increased from 2000 onward. Moreover, it shows a growing concentration of intangibles in lead segments of the chains, i.e. in the distribution stage for buyer-driven GVCs and in activities before the final production stage for producerdriven GVCs (Timmer et al., 2017).

All these works suggest that increasingly the economic dynamics of GVCs depend on the function of intangible assets. Nonetheless, to the best of our knowledge, there has been no systematic treatment from a theoretical or historical perspective of intangible assets in the understanding of GVCs or, more broadly, of the relation between trade and economic development.

\subsection{Intangibles and monopolization in the digital age}

The growing relevance of intangibles for the functioning of our contemporary economies has attracted much interest in the recent years (Haskel \& Westlake, 2018). Intangibles are nonfinancial assets that lack a physical substance, are non-rival in consumption and are at least partially appropriable. Computerized information, technological know-how, artistic original arts, design and new products, brands, employer-provided training and organizational structure are among the main kind of intangibles (Corrado et al., 2012). Such intangibles are not a new phenomenon. Friedrich List, writing in the mid-19 ${ }^{\text {th }}$ century, identified "intellectual capital" as part of the "productive forces" that lay the ground for the production of value and the growth of firms and countries (List, 1856, chap. 2). However, the conditions for the production and consumption of intangibles has changed radically in the past 20 years, with the massive reduction of computation, communication and data storage, intangible assets have defined the modern "information economy." (Nordhaus, 2015, p. 4)

The growing role of intangible assets is limited by the strengthening and broadening of intellectual property rights regulations (IPRs) that restrict their uses in production and consumption. According to the World International Property Organization, IPRs comprise copyrights on artistic and scientific works, industrial property such as trademarks, and patents on new inventions. These IPRs ascribe the legal right to control the use of the intangibles they describe to their sole legal owner. Not all intangibles can be covered by IPRs, but the scope of IPRs hase expanded over time.

The issue of intellectual monopoly gained prominence in the late 1990s. Intellectual monopoly is defined as "the power of producers of ideas to control how their products 
are used" (Boldrin and Levine, 2004, p. 328). Pagano (2014) argues that the tightening of property rights has created a new era -- intellectual monopoly capitalism - in which "monopoly is not simply based on the market power due to the concentration of skills in machines and management; it becomes also a legal monopoly over some items of knowledge". This monopolization has dramatic consequences, since "knowledge is not an object defined in a limited physical space (...) the full-blown private ownership of knowledge means a global monopoly that limits the liberty of many individuals in multiple locations" (Pagano, 2014, p. 1413). IPR rents have been found to be highly unequally distributed (Foley, 2013, Aguiar de Medeiros \& Trebat, 2017), and even to be associated with a slowdown in firm investment as would be predicted by standard monopoly analysis but which also follows Steindl's (1952) notion of maturity and stagnation (Pagano and Rossi, 2009).

The problem of intellectual monopoly is not limited to the issue of IP and must account for the economics of intangibles more generally. Indeed, natural monopoly market structure emerges under various combination of (1) scale economies arising from high fixed costs and low or zero variable costs and (2) network externalities and complementarities (Mosca, 2008)(Haskel \& Westlake, 2018, Chapter 4). Numerous studies have found these features present in internet companies (Haucap \& Heimeshoff, 2014; Khan, 2016) and they have been discussed in the context of multiple-sided markets (Rochet \& Tirole, 2006; Tirole, 2017, Chapter 14).

The spectacular growth in revenue of the leading online platforms - e.g. Facebook, Google, Amazon in the US and Tencent and Alibaba in China - in recent years illustrates the significant first-mover advantages and the enormous returns to scale (Figure 2). Once the internet platform is in place, with its related services available for the first customer, the marginal cost of expanding to even a billion customers is limited or negligible. The situation is compounded by the fact that consumers benefit from having a single platform, such as Facebook or WeChat (Tencent), implying that these firms are close to natural monopolies. The dilemma of a natural monopoly is of course that it requires regulation rather than antitrust policy (Boyd, 2013, pp. 1635-1658) a point we return to in the conclusion. The EU antitrust case against Google is based on its excessive control over downstream markets, and not its monopoly position per se (Daly, 2017). 


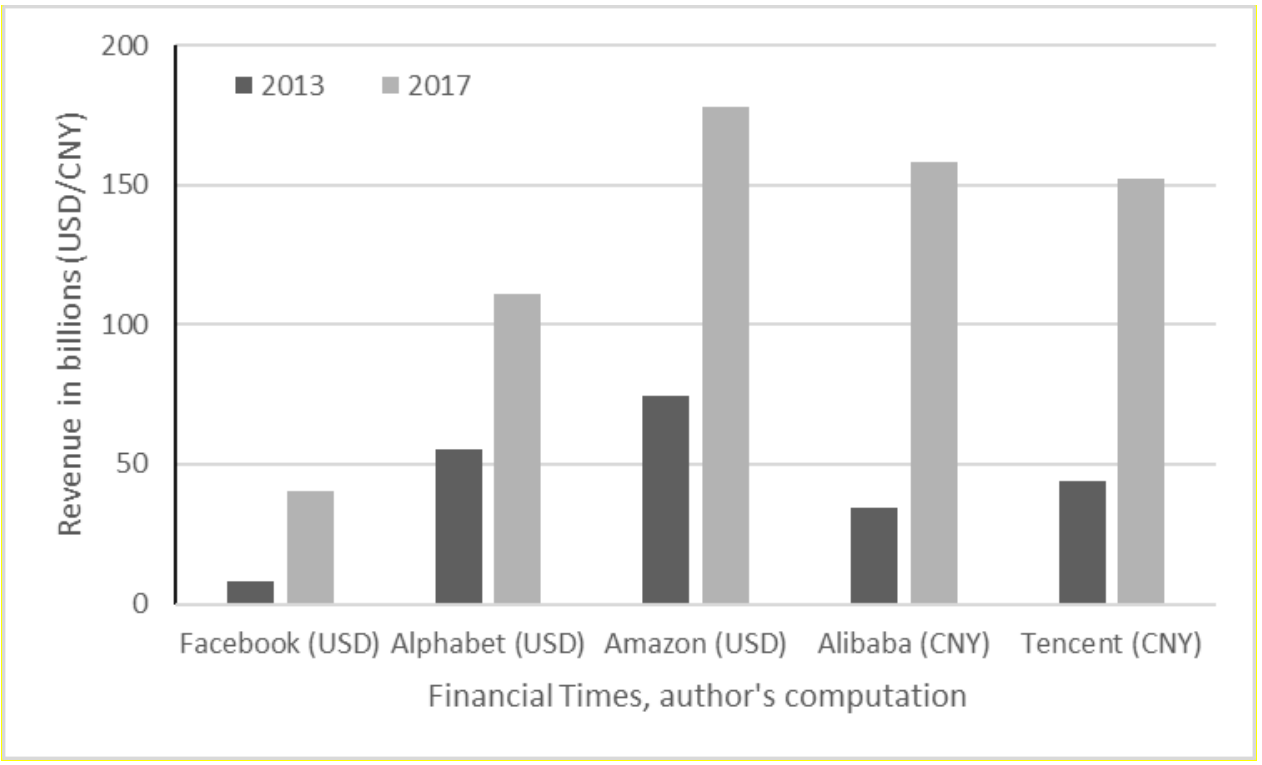

\subsection{Intangibles and coordination of global value chains}

Intellectual monopoly is not limited to internet companies although in the study of GVCs it is acknowledged that the ICT revolution was in part responsible for their expansion. Baldwin (2016) advances the concept of the "second unbundling" in order to stress that ICT revolution boosted globalization by relaxing the communication constraint, which means that manufacturing processes could be dispersed internationally without huge efficiency losses (the first unbundling was the period of expanding final goods trade in the $1^{\text {th }}$ century). However, Baldwin indicates that international fragmentation of production "didn't end the need to coordinate the various stages of production - it internationalized it. Thus to ensure the operation operated as one, the offshoring firms moved their managerial, marketing, and technical know-how along with the offshored stages" (Baldwin, 2016, p. 134). The "need to coordinate" activities previously carried on in-house by big corporations corresponds to a new challenge for management, the integration of business and labor processes distributed among a variety of locations and legal systems.

Sociological research on outsourcing and relocation confirms that increased fragmentation and spatial dispersion of the production process results in a need for coordination. For Ramioul and Van Hootegem "the decoupled tasks involved in producing a single order or customer request remained interdependent. Decoupled tasks need to be linked and coordinated in order to secure seamless processes". However, "remote communication and interventions are more complex and prone to misunderstanding than collocated interaction" (Ramioul \& Van Hootegem, 2015, p. 108). There are also implications for workers who may be confronted with the loss of a comprehensive overview of the workflow and lack the resources to resolve new problems arising from the dispersion. In order to address these new vulnerabilities and 
preserve the integrity of the labor process, ICT tools are implemented while procedures and processes are increasingly formalized and standardized. To realize the matching of production teams and ideas, GVC integration requires a dense circulation of information flows to communicate specifications, standards, technical know-how in addition to costs and other items (Gereffi, Humphrey, \& Sturgeon, 2005). The expansion of GVC trade is thus linked to a rising mobilization and circulation of intangible assets.

\subsection{Endogenous asymmetries of market structures with intangibles}

Milberg and Winkler (2013) propose that the polarization between, on the one hand, oligopolistic lead firms at the top with markup pricing power and concentration of industry and, on the other hand, intense competition among the lower-tier suppliers constitutes an "endogenous asymmetry of market structures" (Milberg and Winkler, 2013, pp. 123-130). They point to global competition as the central mechanism: as more developing countries enter lower- and medium-tech industries in manufacturing and services, lead firms are able to induce competition among their suppliers. Indeed, with abundant labor and excess productive capacity globally at their disposal, lead firms are able to pit suppliers against one another. The situation also allows lead firms to offload productive risks to suppliers.

The so-called "smile curve" ${ }^{1}$ offers a stylized representation of the distribution of valueadded share in GVCs, in which heightened global competition in fabrication leads to deepening of the curve, limiting possibilities to capture value at the central assemblingexecuting segment of the product formation (Figure 3). This deepening of the curve can result from a simple cost accounting effect (Baldwin, 2012, pp. 18-19): if a stage's cost is reduced by offshoring, its share in value added falls since a stage's value added is based on costs, and prominently labor costs. But this cost-accounting effect is both fueled and amplified by changes in relative market power.

The induced competition among suppliers acts effectively as competition among labor. Workers must compete against unemployed workers in their home market as well as against workers across geographically dispersed labor markets. The ability of workers to stand together and bargain collectively for a higher share of income is dramatically weakened by the fragmentation strategy of transnational corporations (Peoples \& Sugden, 2000). As summarized by Nathan and Sarkar (2011): "The splintering of production and outsourcing of tasks enables employers to utilize to the fullest the segmentation of the labour force, and that too on a global scale. Workers in different production units perform different tasks and are paid according to their performance, with no reference to the final product to which the workers contribute. In fact, further down the chain of subcontracting, the workers might not even know the final product, branded or otherwise, to which they contribute" (Nathan \& Sarkar, 2011, p. 54). The

\footnotetext{
1 This representation, originally used by Acer's founder Stan Shih (Shih, 1996) to illustrate challenges for Taiwanese industries in the IT sector, is extremely widely used to illustrate GVCs dynamics in case studies and macro-research.
} 
decline in the wage share in numerous countries that accompanied the expansion of GVC trade between 1995 and 200 is consistent with this weakening of labor bargaining power position due to the segmentation of the workforce (Milberg and Winkler, 2013, (Timmer, Erumban, Los, Stehrer, \& de Vries, 2014, pp. 106-109).

Intellectual monopoly reinforces the deepening of the smile curve depicted in Figure 3. Rather than placing further downward pressure in the middle of the curve, intellectual monopoly points to the upward pressure at both ends of the curve, where control over intangible assets is concentrated. We contend that this upward pressure on each side of the curve comes from dynamics arising from the growing role of intangible assets in chain dynamics and from tighter IPRs. That is, the market power of lead firms is enhanced by intellectual monopoly, which is fueled by a combination of dynamic advantages arising from GVCs network externalities and increasing returns on intangibles and legally-enforced proprietary control over standards, technologies and brands. The remainder of the paper discusses these two sources of intellectual monopoly in the context of GVCs.

Figure 3: Intellectual monopoly versus global competition in the smile curve (Authors elaboration based on Shih, 1996)

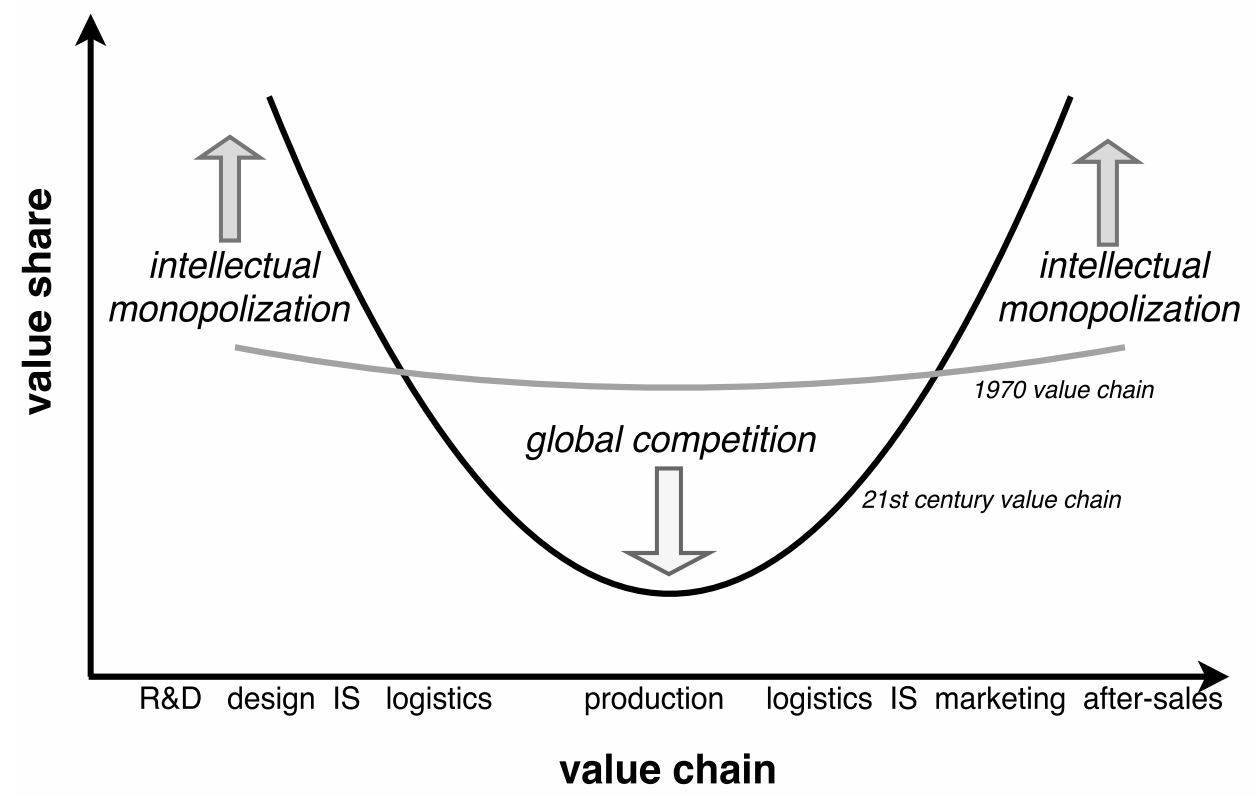

\section{The simultaneous expansion of intellectual property rights and global value chains}

GVC trade expanded rapidly beginning in the 1990s and at the same time that the major industrialized countries began to include intellectual property protections in trade agreements. The share of foreign value added in the exports of the largest economies 
and their neighbors increased markedly (Figure 4). China shows a decline in this measure over the second half of the period, an indication that that production can be "upgraded" to capture more value domestically (Kee and Tang, 2016). Mexico's trajectory suggests that perhaps there is an upward limit to fragmentation. Aggregate WIOT data at the industry/country level confirms the general tendency in Figure 4 with an average foreign value added in gross exports (excluding mining and refined petroleum) that rose from around 19\% in the early 2000s up to $23 \%$ a decade later for the world (Figure 5), a phenomenon slightly more important in advanced economies than in the rest of the world.

This period of GVC expansion coincides with a growing emphasis on the tightening of IP regulations in international trade agreements. The 1980 s represented a period of dramatic change in the U.S. intellectual property law (Coriat and Orsi, 2002; Hunt, 1999). Mounting worries in business and policy-making circles about the deterioration of US comparative advantage in high-technology industries inspired a series of regulatory and institutional changes aimed at protecting US intellectual property. They resulted in enlarged patentability of research results, in particular concerning IT software and in biotech, and stricter enforcement of intellectual property rights. The outcome was a surge in the number of intellectual property applications. This IP frenzy has become a global phenomenon since the turn of the millennium. According to the World Intellectual Property Organization patents and industrial design filings worldwide tripled between 2001 and 2015 and trademarks applications more than doubled over the same period (WIPO, 2016).

Figure 4: Foreign Value-added in exports of the 7 biggest economies, Mexico and Poland (1995-2011)

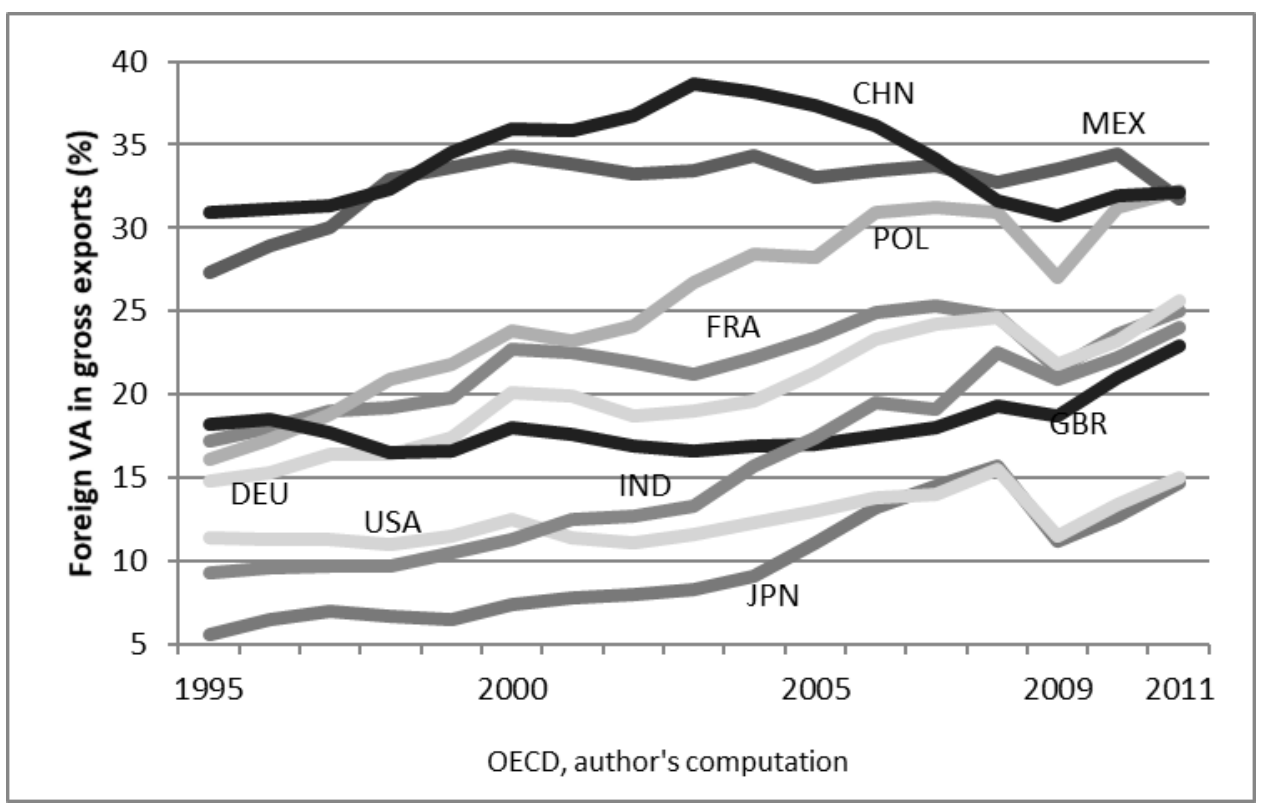


Figure 5: Industries foreign value added in gross export by country grouping

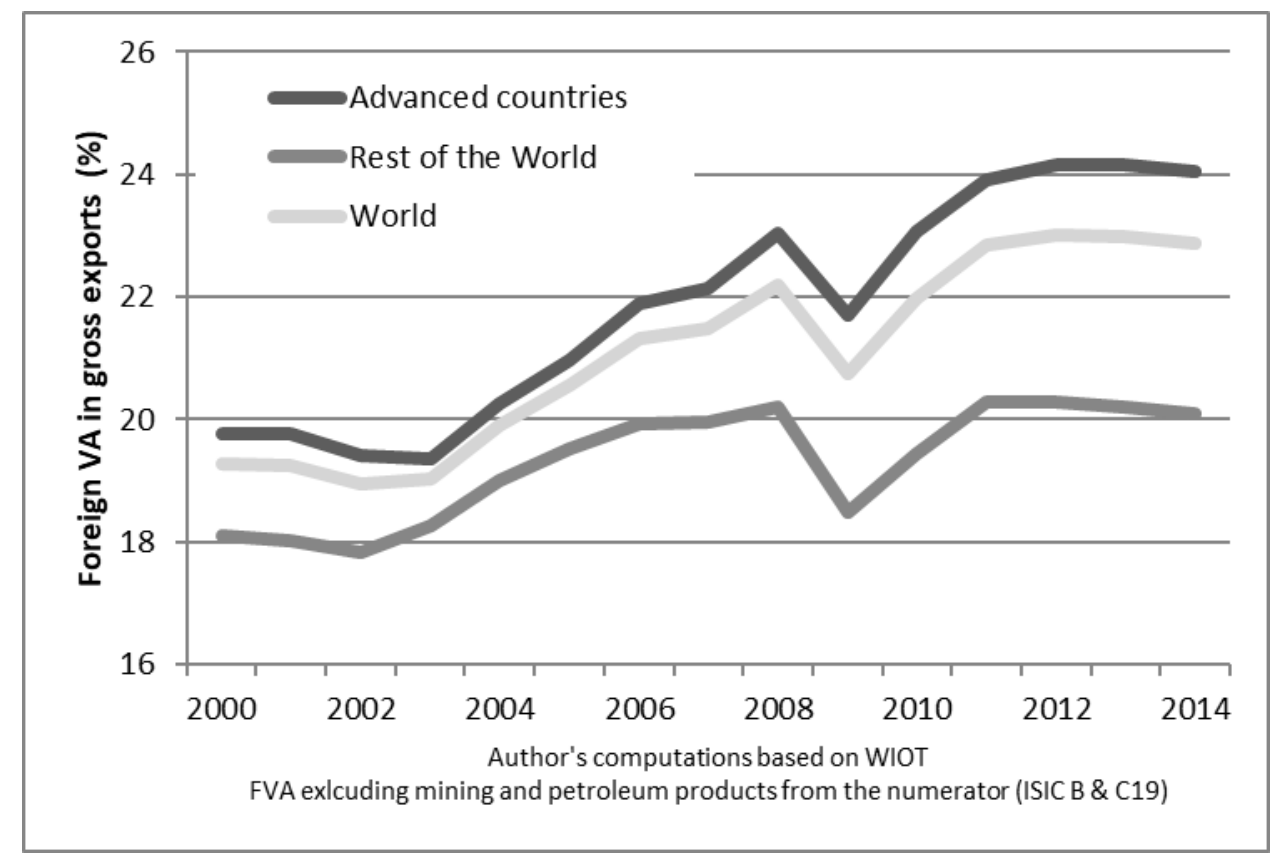

\subsection{The internationalization of IP regulation through trade agreements}

Stricter IPRs at the national and international level support the expansion of GVC-based trade. Since the 1880s, the Paris and Berne Conventions - currently administered by the World Intellectual Property Organization (WIPO) - set some standards in terms of protection of industrial intellectual property and artistic works. However, their implementation has been problematic and no IP case has ever been subjected to the International Court of Justice. In the late 1970s, US IP-based industries realized that their competitive advantage was vulnerable as technological change made replication of their software, recorded music, videos, and pharmaceuticals increasingly easier and cheaper, in the absence of credible institutional means to sanction IP appropriators in developing countries. In the 1980s, they successfully lobbied the US government to use threats of unilateral trade sanctions to force developing countries to increase their IP protection and enlisted business associations in Europe and Japan to oppose what began to be framed as " piracy" and in favor of a stricter international IP regime. (Sell \& Prakash, 2004, pp. 154-160).

\section{Intellectual property in the multilateral trade agenda}

Beginning in the mid-1980s, a mounting number of IP conflicts between the US or European Community, on the one hand, and developing countries, on the other hand, led to unilateral redress under national laws. For example, in 1988 President Reagan decided to impose increased import duties of 100 percent ad valorem on certain products of Brazil due to the Brazilian government's failure "to provide process and 
product patent protection for pharmaceutical products and fine chemicals, and that this failure is unreasonable and constitutes a burden or restriction on U.S. commerce" (Reagan, 1988). Facing trade retaliation, developing countries agreed to include IP in international trade negotiations. A new intellectual property regime began to spread beyond the US borders with an IP chapter of the the North America Free Trade Agreement (NAFTA) in 1994 and, the following year, the agreement on Trade-Related Aspects of Intellectual Property Rights (TRIPS) within World Trade Organization.

As noted by US congressional officials, NAFTA was "the most comprehensive free trade agreement (FTA) negotiated at the time" and served as a template for the new generation of FTAs that the United States later negotiated, and for certain provisions in multilateral trade negotiations as part of the Uruguay Round (Villareal \& Fergusson, 2017). With NAFTA and TRIPS, for the first time, international treaties would subject IP standards to effective dispute settlement, i.e. "compulsory third-party arbitration, including a final ruling requiring treaty compliance and a procedure to enforce decisions" (Hertz, 1997, p. 267). Under the NAFTA, intellectual property disputes can be settled with the dedicated state-to-state mechanism, but because the agreement also protects IPRs as "intangible property", the IP owner has the additional possibility of bringing the host state into binding international arbitration. Under the TRIPS agreement, the Dispute Settlement Understanding, originally designed for trade issues, is applied to IP disputes. This means that the complainant, if found in the right, could be allowed to retaliate by using restrictions on imports against the party violating IP standards (Kennedy, 2016). In addition to this settlement mechanism, the TRIPS give some guidelines for the enforcement of IPRs, resulting in the introduction of some sorts of IP protection in most parts of the world (von Lewinski, 2016). Some Latin American countries did not have pharmaceuticals patents as of the late 1980s, but these patents are now standard everywhere, although there remain differences across countries in terms of such issues as the duration of exclusivity or the possibilities to use test data and compulsory licenses (Shadlen, 2017).

The 2001 Doha declaration asserts that WTO members may have some flexibility in implementing TRIPS agreement in a way that protects public health. This statement is consistent with the fact that the TRIPS agreement only requires countries to provide "minimum" standard of intellectual property protection, which permits compliance with TRIPS while also recognizing the legitimate pursuit of domestic priorities. China used this flexibility to preserve some developmental space to sustain its catching-up as it joined WTO in 2001. The Chinese have since adopted a domestic IP framework and strengthended it over time. (Yu, 2017)2. However, as the Chinese economy expands and its share of world trade grows, the US has become increasingly hostile towards China on

\footnotetext{
2 Chinese authorities are not challenging the western narrative about IP protection. For example, a Siemens IP executive quoted approvingly the Chinese Minister of Science,and Technology as saying: "Patent protection is the respect for human work. Whoever created a patent and worked hard for it must be able to protect the result. If someone steals it, he violates a fundamental right." (Ma, 2008).
} 
issues of IP protection. Businesses and government officials point to China as the main culprit globally of "IP theft" related to counterfeit tangible goods, pirated software, theft of trade secrets and forced technology transfers with estimated losses of several hundred billions of US dollars per annum (Blair et al., 2017; USTR, 2017). It is not evident that China violates any WTO IPR norms, even if a previous dispute in this arena resulted in amendments of the Chinese Copyright Law and revision the Regulations for Customs Protection of IPRs (WTO, 2010). The Trump administration has retaliated against China, with action under section 301 of the US Trade Act of 1974 which provides the U.S. executive branch with the authority to respond to certain foreign "unfair" practices not covered by trade agreement, with a WTO petition against Chinese IP infringement, and with threats of additional actions against Chinese exports to the US.

\section{Strengthening IPRs through preferential trade agreements}

The contention over IPRs exemplified by the dispute between the US and China, reflects the heightened sensitivity of the US and other high-income economies to IPRs in an era where their governments and businesses consider innovation as their main competitive advantage. The US today is the leader of the movement toward stricter international IP norms, in contrast to its position in earlier periods (Peng, Ahlstrom, Carraher, \& Shi, 2017). It is the most active complainant at the WTO under the TRIPS agreement but, as illustrated by the recent actions of the Trump administration, TRIPS is not enough (Sell, 2010). The US seeks other ways to extend internationally the standard of IP protection found in U.S. law and in particular to apply existing IP protection to digital media (Akhtar \& Ferguson, 2011, p. 25).

In order to circumvent the flexibility in the WTO TRIPS Agreement, and the reluctance of developing countries at the WTO to raise WTO standards of IP protection (Helfer, 2004), developed economies have relied increasingly on bilateral and regional preferential trade agreements (PTAs) to accomplish the objective of securing intellectual property related economic advantages (Abbott, 2006; Shadlen, 2008).

The international intellectual property policymaking arena has grown ever more complex with overlapping transnational norms. For example, the 33 pages of the chapter dedicated to IPRs in the US-CAFTA agreement details the treaties and conventions that the parties shall ratify, which defines precisely and extensively the scope of IPRs concerned (copyrights, performance, patents, communication, trademarks, plants, microorganisms, industrial design, geographical indication, name domains...). Additionally, it describes enforcement mechanisms to be implemented in national legislation and considers supplementary protection of intellectual property under the investment chapter (CAFTA, 2004). IP provisions included in Japanese and EU international trade agreements are more general but they also provide supplementary coverage and additional obligations (Liberti, 2010). Moreover, investment treaties and chapters dedicated to investment protection in trade agreements open additional routes 
for IP protection, which can exercise a powerful chilling effect on government actions via the exposure to the risk of costly investor-state arbitration disputes (Ho, 2015, 2016; Kasolowsky \& Leikin, 2017).

The DESTA database (Dür et al., 2014) allows us to track this qualitative evolution in bilateral and regional trade agreements. IP provisions of trade agreements were nonexistent before the North American Free Trade Agreement (NAFTA) was signed in 1992. They became a standard feature of trade agreements in the 2000s. Figure 6 shows the number of PTAs signed each year and of those, the ones which included IPRs. It also shows the percentage of PTAs with an IP provision. By 2016, every PTA signed included an IP provision.

The US, its close Latin American allies and European countries were the first to be involved, but the movement spread-out in Asia in the 2000s, as Japan and China engaged in several PTAs with IP provisions (see Figure 7). Although China is still not involved in any such agreement with the US or the EU, it has signed in 2014 and 2015 agreements containing comprehensive chapters on IPRs with Australia, Switzerland and Korea, which signals a Chinese convergence towards the strict international IP regime championed by high-income countries (Guo, 2016).

Figure 6: IPRs provisions in preferential trade agreements (1948-2016)

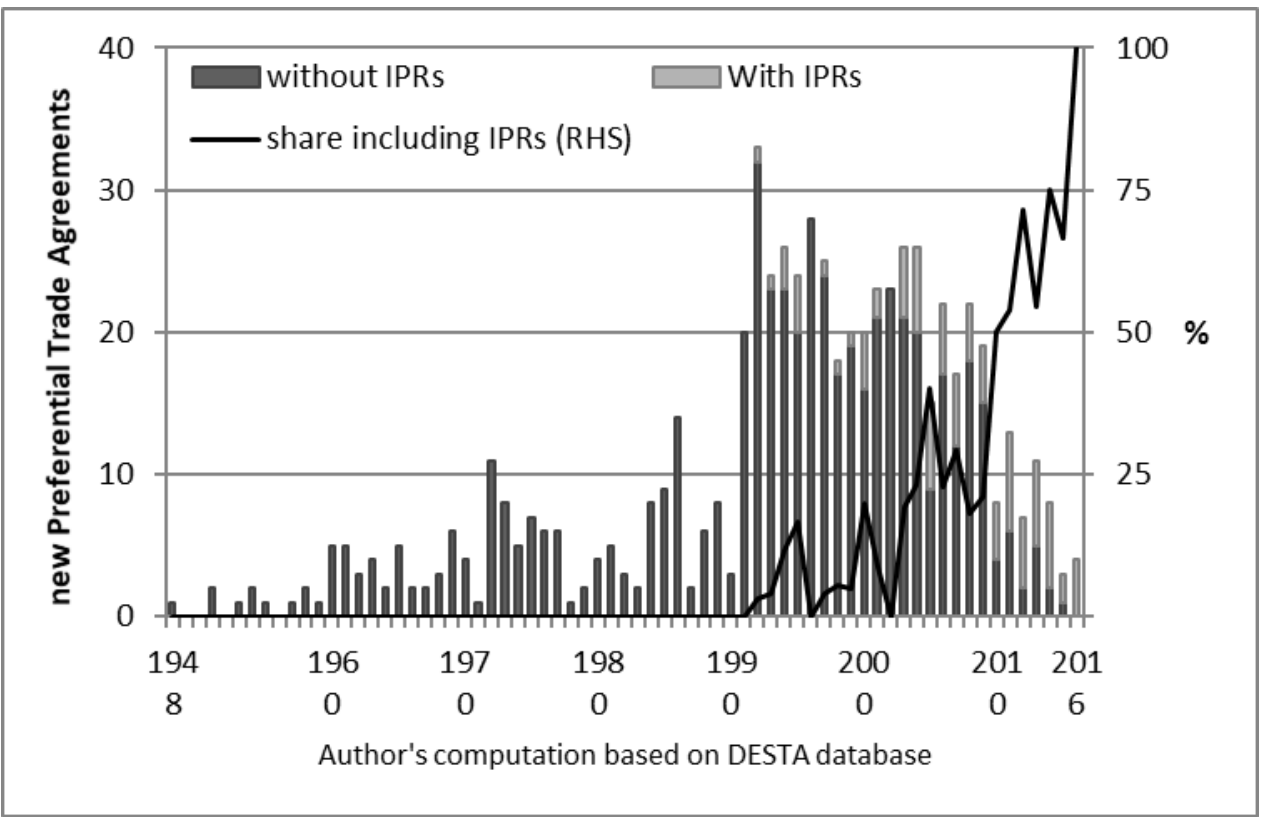




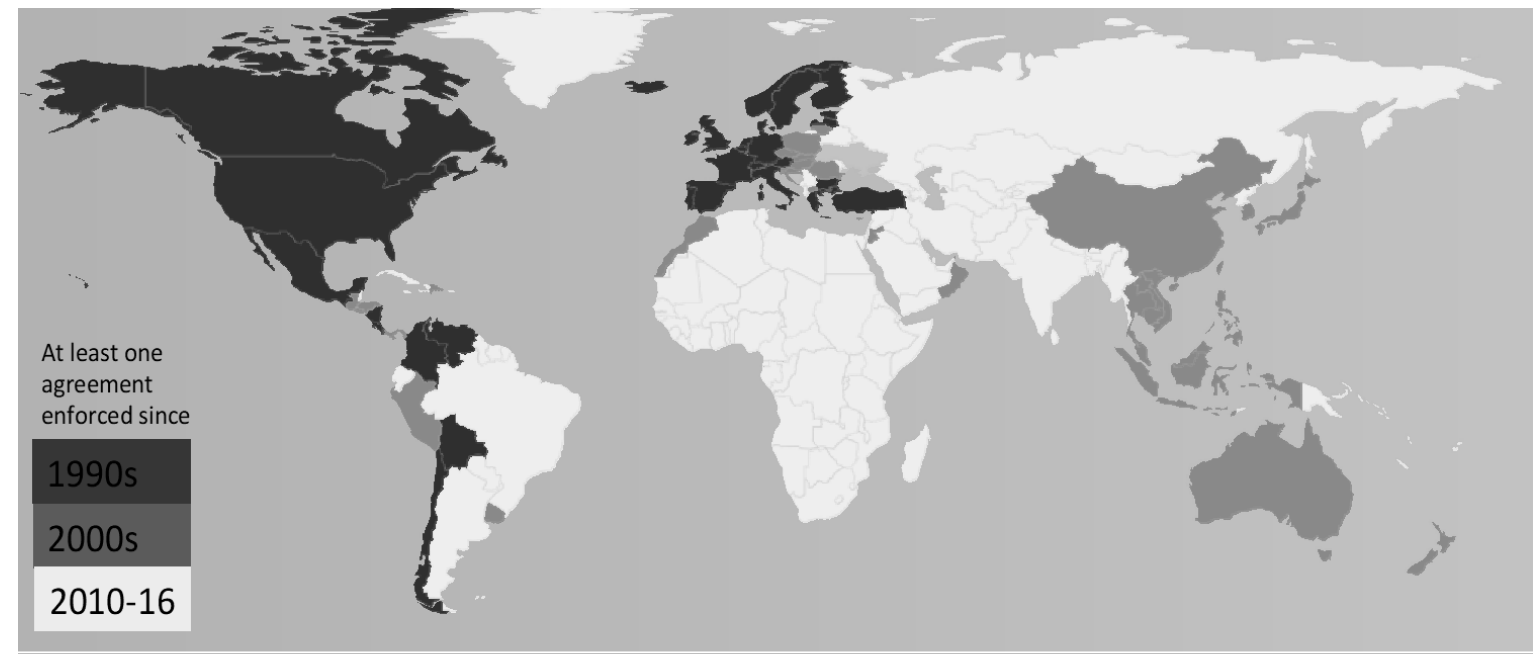

Author's computations using DESTA database

\section{The overwhelming dominance of the North in IP}

The increasing diffusion of PTAs including IPRs provision indicates a global tightening of IPRs. However, the actual content of IPRs provisions can differs substantially from one to another. The higher level of IP protection is provided by agreements involving the US, the European Free Trade association (Iceland, Liechtenstein, Norway, and Switzerland) and the European Union, while trade agreements including only developing countries tend to have much more limited IPRs provisions (Valdés and McCann, 2014). These differences reflect the distinctive motivations of developed and developing countries; while the former aim at narrowing the gap between national regulatory policies, the latter objective is mainly to secure and stabilize market access (Manger and Shadlen, 2014).

The rationale behind these different approaches is clear: patents and international trademark are overwhelmingly concentrated in developed economies, mainly in Japan, US and EU countries. Together, these three entities accounted for $82.5 \%$ of triadic patents - i.e. patents registered at the three major patents offices (US, EU and Japan) - in 2013 (Figure 8). This was actualy a decline from a share of 93\% in 2000, but among developing countries only China made its way to the top ten and still accounts for just $3,5 \%$ of these patents. International trademarks are also heavily concentrated by these three powers (Dernis et al., 2015, fig. 2.8). Moreover, the OECD indicator of the international intensity of trademarks relative to GDP shows that no developing country is ranked in the top 20 (Figure 9). 


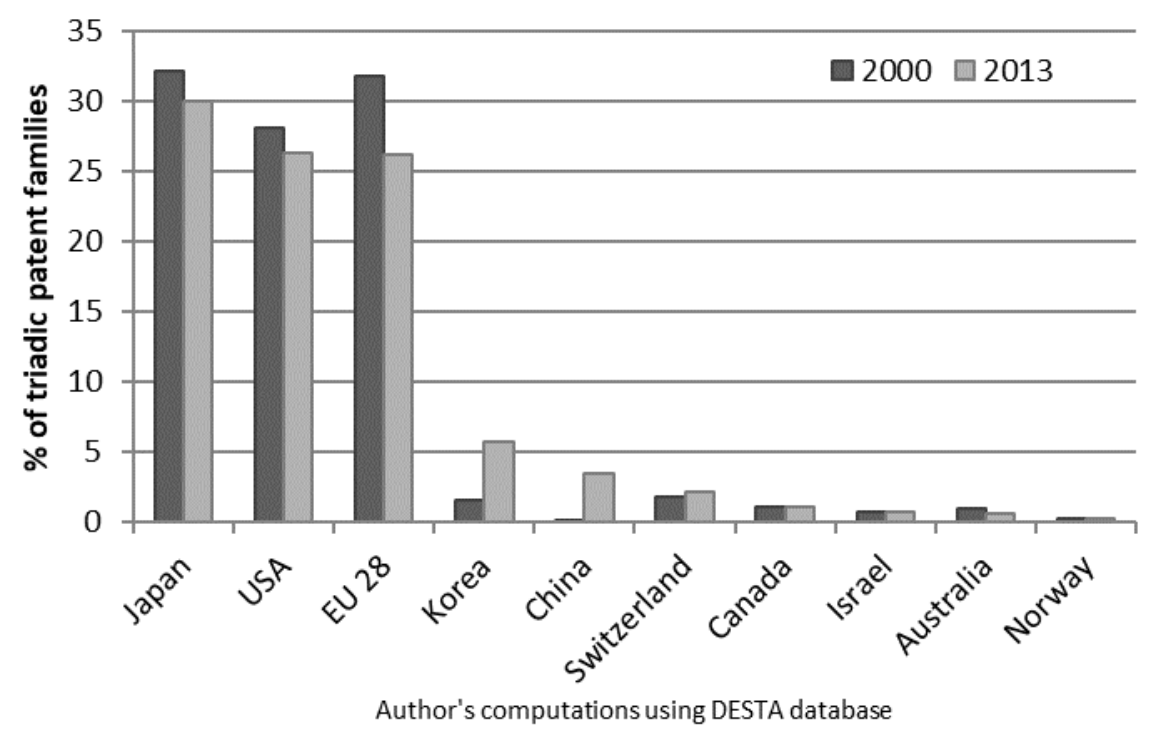

Figure 9: International trademarks intensity in 2010-2012

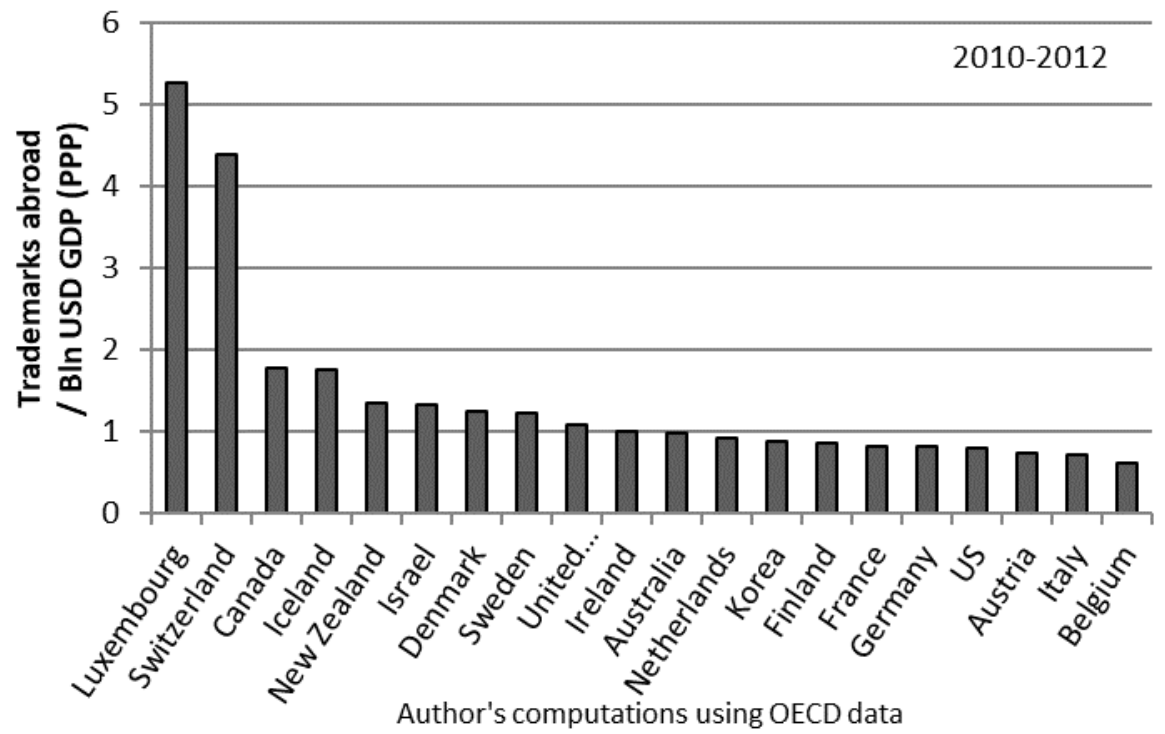

It is important to note that if we consider total patent filings in all national offices worldwide, China is catching up. Trademarks and industrial design filings at China's office took off in the 1990s, and at the turn of the millennium China's office became the largest in the world in terms of applications received. China's office also ranks first for patent filings since 2011.

Despite the gains, Chinese intellectual property does not match the quality of its richer counterparts (WIPO, 2016). Balance of payment receipts from the use of intellectual property testify to the continued control by developed countries. From the mid-eighties to the early 2010s, the spectacular increase of international IP income has gone mostly 
to industrialized countries. International receipts for the use of IP going to high-income economies in 2016 were more than 100 times higher (US\$ 323 billions) thank those going to low- and middle-income countries (US\$ 3 billion) (Figure 10). Moreover, receipts are heavily concentrated in a handful of rich countries, the US alone accounting for $38.4 \%$ of total international payments in 2015 (Figure 11).

Figure 10: High income and Low and Middle Income countries receipts from the use of intellectual property (1970-2016)

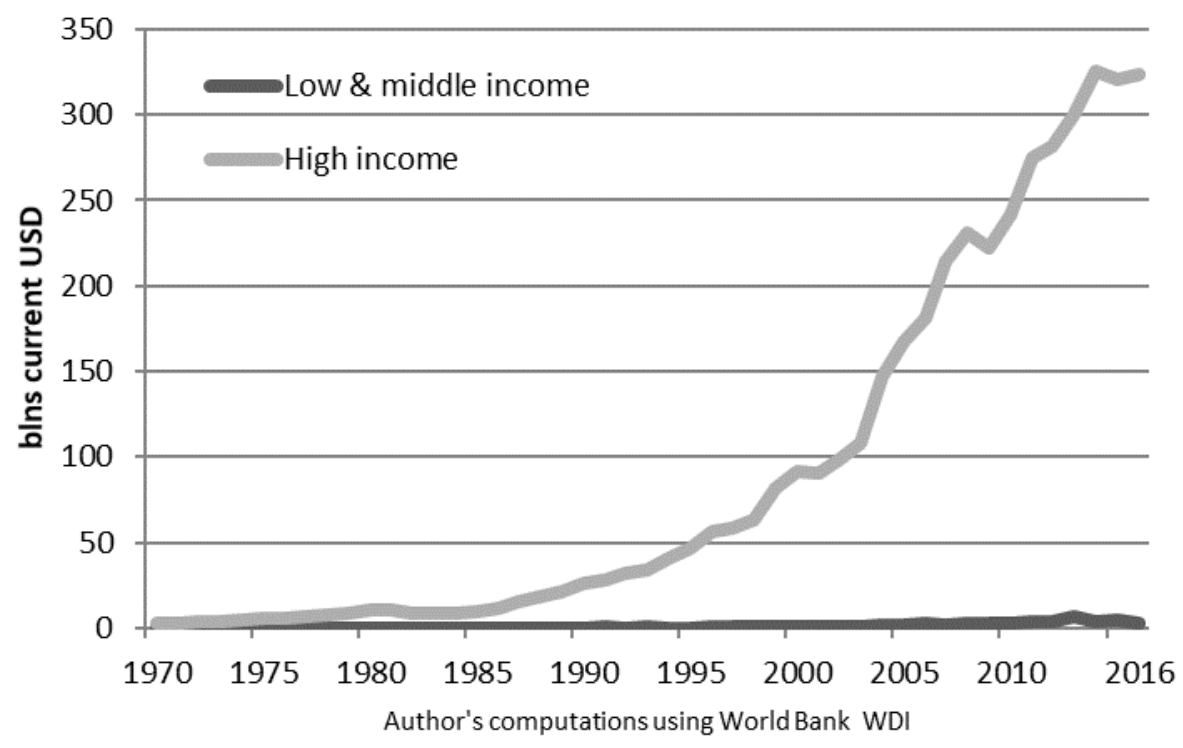

Figure 11: Share of main receiving countries in total receipts for the use of intellectual property (2015)

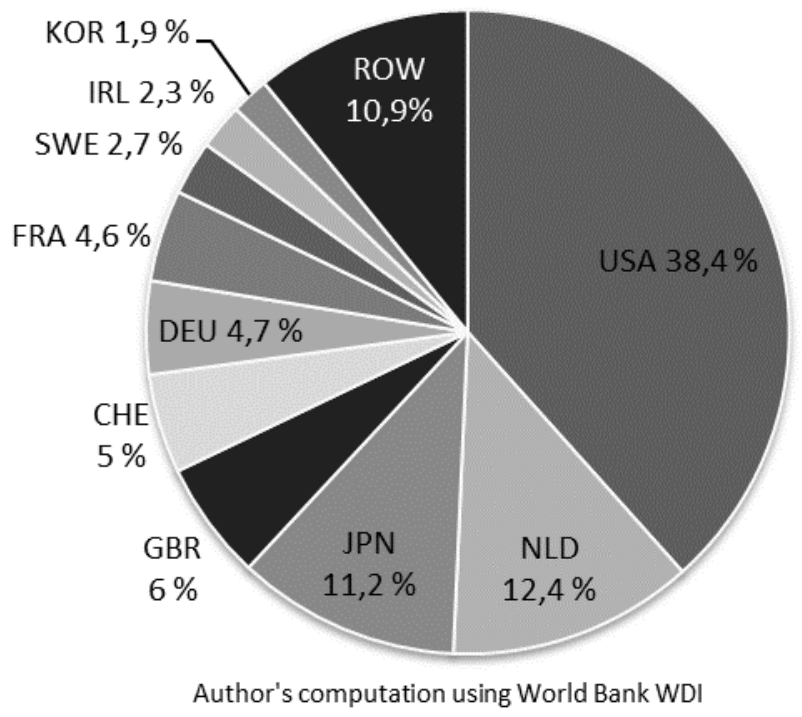

In sum, the stricter IP regime initiated by the US in the early eighties spread rapidly to Europe, Asia and Latin-America. The exception was countries that export mostly primary products or that are big enough to resist this agenda, including Russia, India 
and Brazil. Indeed, IP is still overwhelmingly concentrated in a few developed countries. Even if China is catching up as it develops a dynamic domestic IP regime, the international IP-related payments indicate a crushing dominance of high-income countries, which is both the rationale and the result of their crusade for stricter IPRs over the past decades.

\subsection{Historical and theoretical perspectives on IP regulation and development}

The internationalization of IPRs occurred in spite of the lack of substantial evidence in favor of stricter IPRs for developing countries. The theoretical justification for IP protection arises from market failures resulting from the specificities of knowledge, to the extent it can be likened to information. The "indivisible nature" of knowledge entails a problem of free riding: because the benefits are accessible to everybody while only the researching or innovating entity bears the costs, there is a danger of underinvestment in knowledge production (Arrow, 1962; Nelson, 1959). The state must subsidize knowledge production or strictly enforce property rights on products in order to obtain a sufficient provision of knowledge.

There is not conclusive evidence supporting the role of tighter IPRs for economic development. Historical research proved that Douglass North's hypothesis according to which the rate of technological change depended mainly on the inventor's ability to capture a larger share of the benefits of his invention (North, 1981) resulted in a grossly overstated assessment of the role of IPRs in the industrial revolution (Mokyr, 2009). An in-depth study on the effect of the most significant shifts in patent policy across 60 countries and 150 years found that the impact of patent enhancing on applications was actually negative, suggesting at least a lack of positive impact of strengthening of patents on innovation (Lerner, 2009). Research focused on the more recent period established the lack of any straightforward relation between stricter IPRs and various innovation measures (for an overview see Hudson and Minea, 2013; Park, 2007) and show that the positive effect of venture capital investment on firms' innovation is more effective within the context of a weaker IP environment (Safari, 2017). Assessment of the regulatory changes in the US established that the strengthening and extension of IPRs had negative effects on incentives to invest, as patent disputes have acted as a substantial impediment to innovative activities (Bessen and Meurer, 2008, 2006). Overall, the weight of evidence from economic history indicates "that patent policies, which grant strong intellectual property rights to early generations of inventors, may discourage innovation."(Moser, 2013, p. 40).

In the context of development and trade, the globalization of IPRs fueled a passionate debate over the issue of IPRs. In some specific cases such as some mid-quality and highquality segments of the wine industry, labels and Indication of Geographical Origin can offers some ressources for developing countries producers to control and increase symbolic value of their products (Ponte \& Daviron, 2011; Ponte Stefano, 2009; Staricco 
\& Ponte, 2015). However, most of the discussion have emphasis the asymmetry between developed and developing regions in terms of IPRs ownership and its consequences in the context of IPRs getting stricter. Some economists expected that short term welfare costs for developing countries could be overcome by medium to long term dynamic gains (Maskus, 2000). But the traditional view that IPRs encourage innovation from which all the regions of the world benefit was met by some prominent critics, including Helpman (1993), who noted that IPRs "only strengthen the monopoly power of large companies that are based in industrial countries, to the detriment of the less developed countries" (Helpman, 1993, p. 1248). More recently, Rodrik (2018) writes that "one needs to assume an implausibly high elasticity of global innovation to developing countries' patents to compensate for what is in effect a pure transfer of rents from poor to rich countries “ (Rodrik, 2018, p. 5) Stricter IPRs may also limit developing countries' policy options, shrinking of their 'development space' as they reduce their ability to design and implement industrial policies (Wade, 2003, pp. 624-627)

The implementation of the TRIPS agreement resulted in an important social and political controversy along these lines. Stiglitz (2008) recalls that, in the mid-1990s, both the President's Council of Economic Advisors and the US Office of Science and Technology Policy opposed the TRIPS, while the special interests from the pharmaceutical and entertainment industries strongly and successfully lobbied in favor (Stiglitz, 2008, p. 1694). This supports the view that stricter IPRs allow certain private actors to increase their influence and enhance their advantages, building up "new enclosures" (May, 2000) at the expense of the general social good.

Empirical studies do not support the general idea that more stringent IPRs play a positive role in developing countries. Studies on US and Japanese multinationals have shown that these firms have reacted to changes in IPR regimes abroad by significantly increasing technology transfer between parent and affiliates (Branstetter et al., 2006; Wakasugi and Ito, 2009). However, using royalty payments and R\&D expenditure to measure technological transfer could be misleading since stricter IPRs call for more royalty payments and $R \& D$ expenses independent of changes in effective technology transfers. Beside these two problematic studies, there is no other evidence of a positive effect of stricter IPRs on innovation or productivity in developing countries. In their research which cover 94 countries from 1965 to 2005, Sweet et al. (2015) use an indicator of export sophistication and show that, for developing countries, IPRs strengthening "has at best a non-significant effect on economic complexity and most often has a negative effect."

Another argument for strict IPRs in developing countries has been their role in attracting inward FDI, thus helping to bridge the "idea gap" with developed economies (Maskus, 1998, Markusen, 1995; Romer, 1993; Teece, 1977). There are two objections to this argument. First, FDI has often not helped developing countries to bridge the ideas gap, since these countries often lack the institutions and market structures neededed to 
capture such gains (Durand, 2005). There is not much to expect in terms of positive productivity spillovers from FDI for developing countries. In their meta-analysis, Iršová and Havránek (2013) show that horizontal spillovers from FDI are on average zero (Iršová and Havránek, 2013); vertical spillover to suppliers are economically significant and spillover to buyers are statistically significant but these positive spillovers are generated by investors who have only a slight technological edge over local firms (Havranek and Irsova, 2011) which is generally not the case for FDI from developed to developing countries. They find that the protection of intellectual property rights is insignificant for the magnitude of these vertical spillovers (p. 242).

The second objection is even more straightforward. There is no empirical support for the view that stricter IPRs increase FDI inflows (Nunnenkamp and Spatz, 2004). This finding echoes research on US firms partnering with firms in other countries showing that the degree of hierarchical control is inversely related to the strength of intellectual property protection (Oxley, 1999, p. 288). Indeed, weak protection of intellectual property in the foreign country will tend to raise the cost of relying on contract-based alliances relative to equity joint ventures, thereby encouraging the use of joint ventures - a form of FDI - for a wider range of transactions. There is no evidence of IPRs favoring economic upgrading in terms of export sophistication or positive spillover from increasing FDI.

In sum, there is no convincing evidence of a positive effects of tighter property rights on innovation, productivity growth or FDI inflows in developing countries. Nonetheless, the literature shows that stronger IPRs are associated with trade increases (Awokuse and Yin, 2010; Falvey et al., 2009; Maskus and Konan, 1994; Maskus and Penubarti, 1995; Rafiquzzaman, 2002; Smith, 1999; Weng et al., 2009). As we will see now, this is a key finding that provides support for the hypothesis that GVC trade and stricter IPRs are mutually reinforcing.

\subsection{The complementarity between GVC trade and IPRs}

The late 20th century internationalization of IPRs and the expansion of GVC trade have each been driven by a separate set of factors, but there is a link and we see it in the growing role of intangible assets in international trade. GVC trade is qualitatively different from the traditional exchange of final goods or primary products. It requires intense information flows to coordinate the labor process in parts across countries (see section 2.2). Moreover, the density of these information flows entails a risk of appropriation by would-be competitors, even more than in traditional trade of finished products, where a costly process of reverse engineering is required prior to any imitation (Mansfield et al., 1981). In GVCs, lead firms thus have to weigh the advantages of disaggregating the production process and the cost reduction this can bring against the risk of losing control over some of their proprietary intangible assets. 
Management studies and transaction costs economists have stressed the importance of the IP institutional context for business decisions when there are international alliances, investment and sourcing due to the risk of so called "appropriability hazards" (Oxley, 1997; Teece, 1986). This risk seems to have expanded since the 1990s, although there are some early testimonies from chemical and information industries reporting a reluctance to transfer advanced technology in countries with weak intellectual property regimes (Mansfield, 1994, pp. 26-29).

From the perspective of transaction cost economics, considering the case of a relation with a foreign supplier or buyer, the risk of IP leakage due to a weak IP environment will tend to raise the cost of relying on contract-based alliances relative to equity joint venture (Oxley, 1999, pp. 287-288; Williamson, 2008, p. 12). From the perspective of management research, careful management of the flow of technology along GVCs is imperative and necessitates strict control over information flows in countries with weak IPRs (Prasad \& Sounderpandian, 2003, p. 246). Adequate governance arrangements, secrecy or restraint to outsource offshore were thus considered as the main way to deal with the risk of IP leaks in GVCs:

\begin{abstract}
Companies can mitigate intellectual property risk by bringing, or keeping, some production in-house, or at least under direct company control. That is a major reason why Motorola owns some of the testing equipment at supplier locations. Managers also can decrease risk by limiting the flow of new intellectual property into countries with weak legal protections. Companies like Cisco, which outsources all manufacturing, also lower risk by creating business processes that cannot be easily replicated by a single manufacturer. Electronics manufacturer Sharp Corp. even repairs equipment itself, thus preventing any possibility, accidental or otherwise, that its vendors will share proprietary information with Sharp's competitors. The company goes so far as to reprogram various computer-aided machines used by its vendors without sharing the information. (Chopra \& Sodhi, 2004, p. 57)
\end{abstract}

In the 2010s, a new field of business research and consulting emerged around the management of IP in global value chains. Its purpose is to circumvent the difficulty of using formal IP protection channels and to find other ways to enforce IPRs without limiting the scope of GVC activity. A first issue is supplier selection to minimize the risk of IP leaks (Wu, Li, Chu, \& Sculli, 2013). There is also an attempt to move beyond legal procedure and use the reporting procedures created for the implementation of Corporate Social Responsibility to enforce stricter IPRs standards along the chains (Gillai, Rammohan, \& Lee, 2014). The Center for Responsible Enterprise And Trade (CREATe.org) was founded in 2011 with the support of start-up grants from the Microsoft Corporation with this objective of fostering "a culture of IP protection and compliance" throughout the global supply chain. This agenda is becoming mainstream, as it was endorsed by the World Intellectual Property Organization in its annual report dedicated to Intangible Capital in Global Value chains (WIPO, 2017).

These business developments illuminate the relation between GVC trade and IPRs. Lead firms engaged in GVC trade are interested in stricter IPRs in trade agreements to contain 
the risk of IP appropriation resulting from the international fragmentation of production. At the same time, the strengthening of IPR provisions in international treaties can contribute to a deepening of GVC trade since these provisions encourage innovative firms to engage in GVC transactions without fear of losing control over their own innovations. With data on 119 countries over the period 1976-2010, one study finds that the impact of strengthening IP protection is significantly stronger for imports of more technology-intensive products, which suggests that by conforming to the minimum standards of intellectual property protection set out by the World Trade Organisation, the middle-income countries have benefited most in importing technologically advanced products (Chen, 2017). This has pushed the case for IPRs beyond the product and piracy argument that is often thought to drive the IPR debate in trade negotiations and towards the idea that the introduction of global IP standards favor transfer of technology by multinational corporations to developing countries (Hanel, 2006, pp. 915, 924).

The attempts of innovative firms to protect their IP when participating in GVCs puts them at odds with the interest of actors from developing countries. Indeed, from the point of view of developing countries' businesses and governments, the potentially positive consequences of dense GVC linkages have to do not just with market access but also with knowledge transfer. But it is precisely the fear of losing control of such transfer that makes lead innovating firms to be reluctant to engage strategic intangible assets in GVC relations.

The net effect of the mutual reinforcement of GVC trade and stricter IPRs for developing countries is ambiguous. On the one hand, as IP protection contributes to a denser circulation of intangibles within GVCs, developing countries' opportunities for economic upgrading via productivity spillovers increase with collaboration with betterperforming firms increases (Humphrey and Schmitz, 2002; Kummritz et al., 2017; Milberg and Winkler, 2011). On the other hand, this comes at a price. Wider and stronger intellectual monopoly rights put some limits on the scope of knowledge appropriation by developing country firms, erect entry barriers to some market segments, and fuel rising IP payments. Although there has been no empirical exploration of the net impact of these two effects, the broader literature (discussed above) concerning stricter IPRs in developing countries, suggests that this second and negative effect is the most powerful.

\section{Monopolization dynamics arising from network complementarities and scalability of intangibles}

Stricter international IP norms are a source of intellectual monopoly that accompanied the expansion of GVCs. These legal protections reinforce the basic economic logic of 
intellectual monopoly in GVCs, driven largely by the centralization of network externalities. Three interrelated mechanisms contribute to the process: the appropriation of the gains arising from complementarities, the collection of data generated by the activities along the chains and the uneven distribution of returns to scale. We briefly discuss each of these.

\subsection{Gate-keeping and natural monopoly forces arising from chain integration}

Within GVCs, the value of each component circulating in the chain is enhanced by its combination with other components: conception and development, production, assembly, logistics, marketing, branding, sales and service. It is the network nature of the GVC that results in value being realized. As discussed above (section 2.2), this network complementarity requires enormous oversight to guarantee "adherence to specific technical compatibility standards" (Economides, 1996, p. 677) that enable the compatibility of operations along the chains. Such oversight comes from lead firms taking the responsibility for the coordination of the network and providing the sophisticated informational infrastructure needed to guarantee the appropriate combination of partial-products into full commodities and to accommodate just-in-time adjustments to evolving market and other conditions. This is the very process of the GVC, and it entails specific market structures in different parts of the chain.

\section{Chain integration deepening in historical perspective}

With a changing political environment and new technological developments, integration has deepened dramatically since the 1980s (for a timeline of supply chain management strategies, tools, and techniques see Stevens \& Johnson, 2016, pp. 22-24)). In the early 2000s, reverse information sharing from retailers to manufacturers became more prominent as a result of a confluence of three technologies: enterprise resource planning (ERP) systems, customer relationship management (CRM) systems, and business-to-business (B2B) exchanges (Jain and Moinzadeh, 2005). In the 2000s, the implementation of Radio frequency identification (RFID) technology with the systematic tag of pallets has improved the product flow between suppliers and retailers, improving inventory management efficiency (Shin \& Eksioglu, 2014). However, although this deeper integration relied heavily on suppliers investments, retailers appropriated most of the substantial efficiency gains (Baud \& Durand, 2012, sec. 5).

Initially, information sharing mainly concerned final product demand and inventory control. But it expanded to other items such as quality controls through dedicated software, for example in the automotive industry (Batson and McGough, 2007; Liker and Choi, 2004). Zara's Inditex illustrates another dynamic, where apparel point of sale (POS) data and customers comments on social media are used to drive reactive design and near-shoring manufacturing, allowing new design to arrive in store within 15 days 
of concept (Aronow, Ennis, \& Romano, 2017; Christopher, 2000; Tang \& Tomlin, 2008; Tokatli, 2008).

Apple is an even more radical case due to the complexity of its products and industrial processes. The firm abandoned its factories of Fountain in Colorado Springs and Elk Grove in Sacramento in 1996 and 2004 (Barlett \& Steele, 2011) and generated a veritable industrial renaissance based on value chains management capabilities, becoming the most renown factory-less goods producer in the world (Bernard \& Fort, 2015). Apple makes none of its products itself. All manufacturing is performed by other firms in China and elsewhere. Nonetheless, the firm built "a closed ecosystem where it exerts control over nearly every piece of the supply chain, from design to retail store." (Satariano \& Burrows, 2011). Apple innovation capabilities goes beyond design, development, marketing and the creation of the software to include the technical features of the parts of its products but also the improvement of the means of producing these products. While manufacturing subcontractors do the actual production, manufacturing equipment design and capability are a distinctive competitive advantage of the company. Suppliers who provide some intellectual property to the process face a risk that Apple can abruptly sever its purchases in order to take control of what it considers to be strategic technologies, as the GPU chip designer Imagination Technologies learned at its expense when it was abruptly sidelined by Apple in 2017 (Barrett, 2017; Bradshaw, 2017). According to industry specialists, what is at stake is the ability of the Apple to optimize the design of the processors for the specific function of its products and to allow customization in order to differentiate its devices and keep competitors at bay. To be effective, these manufacturing capabilities without direct ownership of manufacturing operations rely on a distinctive ability to integrate the operations, i.e. an organizational and information system that coordinates and monitors the dispersed productive operations processes in a coherent labor process. This is a key asset of Apple and an obligatory passage for its suppliers to get access to their enormous consumer end market.

The trend toward greater integration within GVCs continued with the early deployment of the internet of things (IoT) (Atzori et al., 2010; Wortmann and Flüchter, 2015). The industrial internet consortium, which was formed in 2014 with the support of GE, AT\&T, Cisco, Intel and IBM, aims at developing standards to foster the implementation of internet-connected technologies to the many objects and parts circulating across industries. Industry 4.0. is a competing framework initiated by the German government to safeguard a sustainable competitive advantage for the German manufacturing base through the deployment of Cyber Physical Systems (hardware systems with embedded software) (Hermann, Pentek, \& Otto, 2016). Such complex information systems are an integral part of the emerging architecture of GVCs as networks combining Internet of Things (IoT) sensors, cloud computing and advanced analytics. In its 2017 Global supply chain top 25 report, the consulting firm Gartner describes this emerging trend, stating that "The digital pieces of the supply chain puzzle 
are coming together in a way that will enable more holistic, real-time management of the entire ecosystem" (Aronow et al., 2017).

\section{The economic advantage of building and controlling the chain infrastructure}

Over the past decades, the progressive deepening of GVCs toward "more holistic, realtime management of the entire ecosystem" result from the building of informational backbones and management know-how that sustain the circulation of information and physical flows. These are intangible assets. By providing the network with an organizational integration framework, leading integrators occupy a singular position vis-à-vis other participants. Because the firms that coordinate the chain allow the other participants to participate in the network and, consequently, to enhance the value and/or volume of their activities, they are in position to reap a disproportionately large share of the enhancement of value created through network cooperation. This is the case because natural monopoly features protect the integrator market power.

A natural monopoly is a market structure where some combination of economies of scale (high start-up costs and low marginal costs), sunk costs (irreversibility of the initial investment) and the presence of positive network externalities (complementarities between uses) result in a sub-additive cost function, where only one firm find it profitable to produce (for a review see (Mosca, 2008)). All these forces contributing to the formation of natural monopoly are present in the process of value chain integration: First, there are significant fixed costs associated to the building of the informational and organizational infrastructure of a value chain; Second, these costs are to a large extent sunk, and thus such intangible assets are dedicated to a specific purpose and cannot be redeployed without tremendous loss; and third, complementarities between participants make it difficult to leave a given value chain or to build a competing one. In such a configuration, market forces alone are unlikely to reduce market power (Motta 2004: 71). In contrast with the traditional natural monopoly literature, the emphasis of the GVC perspective is not horizontal competition between producers but vertical competition between firms contributing to the production of the same family of goods. What is at stake in the competition process is thus the control of the gains arising from the cooperation along the chain. Organizing fragmentation is instrumental to the centralization of profits.

It is important to note that in GVCs it is generally not the case that one single firm takes responsibility for the integration of the whole chain (Gibbon, 2008, pp. 37-38). Most of the time, several lead firms are involved in oversight of the chain, distributing unevenly some degree of control over the whole integration. This is the case for example when the leading subcontractor takes full responsibility for the coordination of some part of the upstream segments, for example first-tier suppliers like Bosch and Valeo in the automotive industry (Humphrey, 2003; Caputo \& Zirpoli, 2002) or giant contract 
manufacturers or traders such as Foxconn in electronics, Yue Yuen in footwear and Li \& Fung in the textile and apparel industry (Gereffi, 2014, p. 16).

Another category is horizontal overlapping between chains. One can think about firms such as SAP, Oracle or Dassault System that provide business software for a wide range of firms in different industries which allows them to integrate their operations within and beyond the boundaries of their companies. Such software companies, just like consulting firms, are suppliers to lead firms, but their position is specific as they prescribe organizational design and thus have some oversight of the integration process.

In sum, chain integration deepening in GVCs over the past decades has involved a growing role for information system in the coordination of unbundled activities. In this process, the combination of sunk and irreversible costs and network effects generates natural monopoly forces that allow lead (integrator) firms to capture a disproportionate share of the mutual gains of cooperation. Natural monopoly power may in some cases be dispersed across a few firms depending on the degree of contribution to the oversight of the integration process and to the share of the positive externalities arising from network complementarities that firms involved in GVCs can appropriate.

\subsection{Innovative advantage of centralizing the data}

The accumulation of data is at the heart of the business model of giant internet companies such as Google, Facebook, Amazon, Tencent and Alibaba. User-generated data allows these firms to enhance user experience and to design focused advertisements that they sell to other businesses. Alphabet (the parent company of Google), for example, generates $87 \%$ of its income from advertising (US SEC, 2017) and controls $42 \%$ of digital ad market in the US and $33 \%$ in the world (eMarketer, 2017; Molla, 2017). The "acceleration to scale" (Schmidt \& Cohen, 2014, p. 10) that is at the root of the explosive growth of the digital platforms and has put them among the world's biggest corporations in terms of market capitalization ${ }^{3}$ derives from their ability to generate, control and manage data.

The importance of data is relevant beyond internet companies to the wider economy and, in particular to GVC organization. The (partial) centralization of the gains arising from network complementarities is reinforced by another centripetal process: the centralization of information that results from the very process of integration deepening. GVC integration generates huge amount of data through the functional linking of marketing, logistics, operations and sourcing applications, and these data are powerfully leveraged by companies operating at large scale (Sanders, 2016). This accumulation of data from suppliers and customers becomes proprietary data and represents "a core asset that can create significant competitive advantage" (OECD, 2013).

\footnotetext{
${ }^{3}$ As of February 62018,7 of the ten biggest firms by market capitalization where tech companies. These were, by descending order : Apple, Alphabet, Microsoft, Amazon, Facebook, Tencent and Alibaba.
} 
Lead firms that take responsibility for the coordination of GVCs rely on dedicated information systems, whose reach connects them directly to supplier operations and customer behavior. This is the case for Wal-Mart, for example, that connects the activities of its 245 million customers at the rhythm of one million transactions every hour with its logistics and suppliers data. Wal-Mart relies on an SAP software called "HANA business intelligence platform" to assemble data from different parts of the enterprise and visualize it in real time. According to Wal-Mart CIO Karenann Terrell, "HANA is floating on our ERP system. Innovation doesn't rest in the back office."(Wilson, 2015). In Data café, the firm's analytics-hub located at its headquarter in Bentonville, Arkansas, 2.5 petabytes of data fueled by 200 internal and external streams (including meteorological, social media, economic telecom and local event data) are processed every hour. Teams from every department are invited to bring their problems to the analytics experts, helping them to solve complex business questions through statistical queries completed in a few seconds (Marr, 2017).

At the root of this informational advantage is the position of Wal-Mart vis-à-vis its supply base. Through its software Retail Link, the firm is connected to more than 17,500 suppliers. These suppliers can improve their operations as they have access to point-of sale data concerning their own products. In return, Wal-Mart gets a panoptic vision from within of the operations of all of them, concerning their production planning, the design and the conditioning of their products (Sanders, 2016, pp. 32-34; Wang, 2006, p. 59).

The advantage in terms of data gathering is not limited to the systematic centralization resulting from the implementation of the trans-organization information system. Taking advantage of their bargaining power, lead firms try to expand their intimate knowledge of the value chain, asking their suppliers details of their business operations in the course of the contractual negotiations, as it has been reported for Apple:

\footnotetext{
Life as an Apple supplier is lucrative because of the high volumes but painful because of the strings attached. When Apple asks for a price quote for parts such as touchscreens, it demands a detailed accounting of how the manufacturer arrived at the quote, including its estimates for material and labor costs, and its own projected profit. (Satariano \& Burrows, 2011).
}

Another illustration of the hunt for data is the fact that established information technology enterprises such as IBM, SAP, Microsoft, Intel and Cisco, numerous startups but also manufacturers such as Rolls-Royce, GE and Siemens have been investing heavily in "predictive maintenance", i.e. real-time monitoring of equipment in order to optimize scheduling of maintenance work and prevent unexpected equipment failures. For these firms, this is "one of the myriad ways they capture data across the value-chain to improve efficiencies and automate work." (McGee, 2017). Bernd Leukert, SAP executive board member and steering committee chairman of the Plattform Industrie 4.0 initiative, 
describes the tensions resulting from the intertwining of information systems implied by predictive maintenance:

\begin{abstract}
Companies need to be sure that connecting their machines with the machine vendor or a service provider doesn't result in leaks of important customer or production data. A service provider does not need to know which CAD [Computer Aided Design] files you are running on your milling machine, but on the other hand, he needs enough information about the machines, devices, and assets to be able to provide proactive maintenance, thus avoiding costly downtimes in your production environment.(Leukert, 2017)
\end{abstract}

Siemens CEO Joe Kaeser echoes this statement when he explains the strategic issues related to the uses of data resulting from the co-evolution of machinery and digital systems. It is worth quoting him at some lenght:

\begin{abstract}
We manufacture products that generate power, that automate manufacturing processes, that scan people (like CT and MRI machines), and that move people and goods from place A to place B. That's a lot of products, and all those products have sensors. (...), once we get the data, we have the data analytics platform and the cloud. We have a proprietary cloud, for example, an on-site cloud. Our customers care about manufacturing and engineering data and intellectual property rights because [this type of data] is the holy grail of innovation ». (...)

«Data analytics gives a company a lot of information [it can use] to optimize and shorten the value chain. (...) You can make products faster, more cost-efficiently, more flexibly. You can produce in lot sizes of one. You can cut out different links of the value chain. And the links that get cut out provide the least value in the value chain. And that's what you need to understand. "Where am I in the value chain? How can I remain a strong link by providing more value than anyone else in there?" You'd better know what you can do with your data and cut someone else out rather than get cut out yourself. The issue isn't just that your suppliers might try to cut you out. Your customers might try to cut you out because they say, "I've got the data, so why do I need you?" That's the paradigm shift.... (Kaeser \& Gross, 2016)
\end{abstract}

Another interesting illustration of the data implications of the move toward deeper integration concerns the building industry. The Building information modeling (BIM) process allows individuals, businesses and government agencies to plan, design, construct, operate and maintain housing projects, public facilities and physical infrastructure such as utilities, roads, bridges, ports, tunnels, etc. The rapid international adoption of this tool for its powerful data-based modeling, visualization, analysis and simulation capabilities represents a paradigm shift for the construction industry. Increasing integration of operations favors the industrialization of the whole building production process and allows for the implementation of lean management technics. As a result, "The power is shifted upstream in the design stage and the construction site becomes more and more standardised with little room for change."(Davies et al., 2015, p. 1143). Bouygues construction, one lead firm of the sector in France developed, with consulting firm Accenture and software designer Dassault Systèmes, one such digital 
environment for construction project management. This system is based on Dassault Systèmes' 3DEXPERIENCE platform, which is already used in other industries including automotive and aerospace. According to its initiators, what is at stake with this project is that by employing all project data across the board, this solution would guarantee greater efficiency. But there is something more. As explained Bernard Charlès, CEO of Dassault Systèmes, it is changing the dynamics of value capture along the chain:

"The 3DEXPERIENCE platform gives Bouygues Construction a unique opportunity to be the pioneer in the construction sector with business processes and a holistic approach integrating the company and its supply chain into a value creation chain.

"Thanks to the parallel exchange of data between the virtual world and the real world, Bouygues Construction will be able to set new standards of efficiency and capture all the business value expected from its digital transformation."(Bouygues Construction, 2017)

There is thus a vertical competitive struggle for the control of data. On the one hand, letting data circulate is a pre-condition for allowing the integration and the optimization of business processes along GVCs. On the other hand, such integration gives disproportionate data access to those who initiate and organize the chain integration. The asymmetric design of information systems and the uneven bargaining power in contractual negotiations allow dominant firms to learn from their partners' businesses processes. Because the control of data is the "holy grail" that gives companies the ability to innovate and cut out their competitors upstream or downstream, the uneven distribution of data along GVCs entails a dynamic and cumulative advantage for firms that plays a lead role in chain integration.

\subsection{Uneven intangible intensity and the uneven distribution of returns to scale}

We turn now to a final mechanism related to the distinctive nature of scale economies of tangible assets compared to intangible assets. Intangible assets such as standards, specifications, R\&D achievements, as well as software and organizational know-how are typically scalable assets. They impose negligible marginal costs following the initial investment made to create them. This results in infinite returns to scale. The role of intangible assets looms large in current competitive dynamics, for example, in the growing rivalry between Walmart and Amazon. According to a report in The New York Times:

"Retailers need to figure out how to manage sophisticated supply chains connecting Southeast Asia with stores in big American cities so that they rarely run out of product. They need mobile apps and websites that offer a seamless user experience so that nothing stands between a would-be purchaser and an order. (...). Larger companies that are good at supply chain management and technology can spread those more-or-less fixed costs around more total sales."(Irwin, 2017) 
This feature is in striking contrast with tangible assets: even if tangible assets exhibit some increasing returns, these are certainly finite, and their physical nature makes them subject at some point to diseconomies of scale. Now consider the fact that along GVCs some segment are intensive in tangible assets -- the manufacturing of clothes, the assembling of food processors, a semi-conductor fabrication plant, railway transportation. Other segments are intensive in intangible assets -- fashion design, integrated circuit or web design, marketing, software coding, supply chain management information system. As the output of the GVC expands, its intangible- and tangibleintensive segments expand at different rates. Due to the uneven distribution of fixed costs, total costs grow more rapidly for tangible-intensive segments and average costs diminish much more rapidly for the intangible-intensive segment. This is illustrated in Figure 12. The difference in scale economies between tangible and intangible assets means that those firms controlling the intangible-intensive parts of the chain will receive a disproportionate share of the gains from the network as output expands. Intangible- intensive segments thus benefit more from increasing GVC output than tangible-intensive firms.

The uneven distribution of returns to scale due to uneven distribution of intangible intensity in the various nodes of a chain is thus a third phenomenon contributing to the centralization of network externalities.

Figure 12: Total and average cost dynamics for tangible intensive and intangible intensive segments (authors' elaboration)

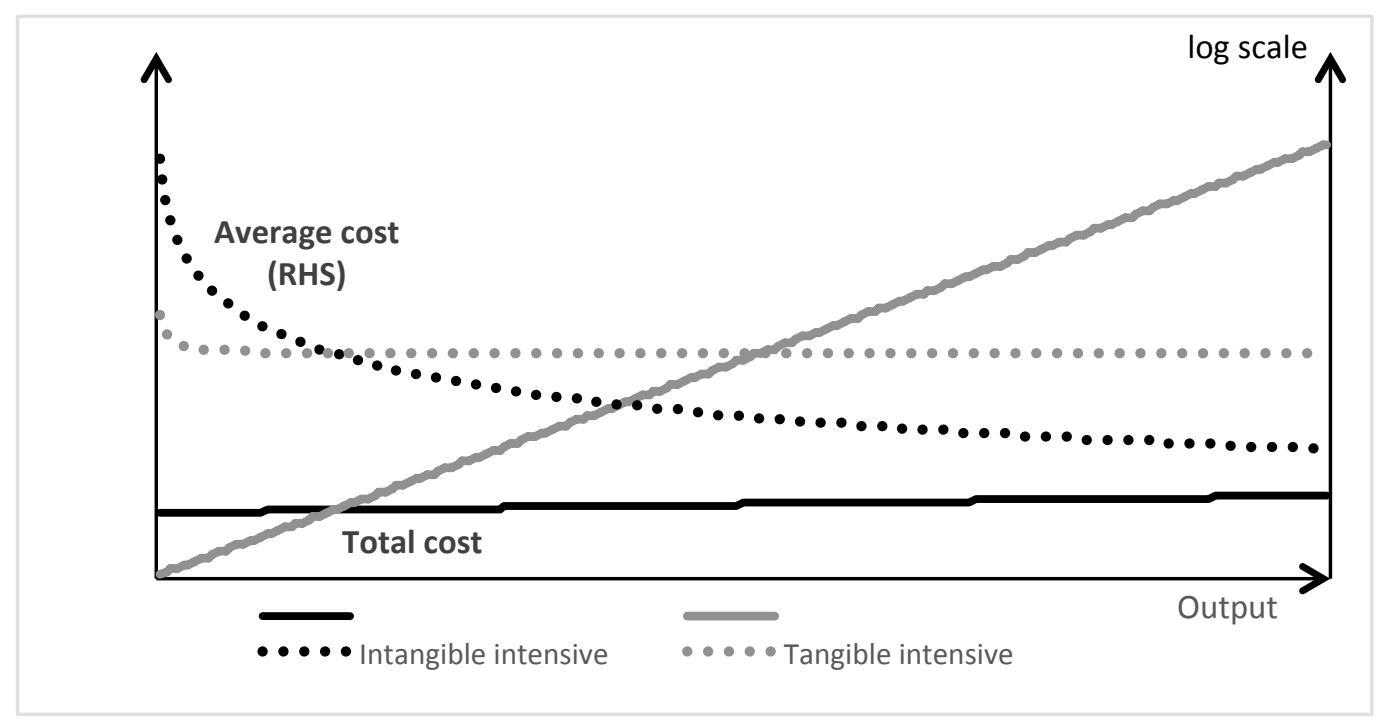

Intellectual monopoly in global value chains results from two distinctive but partially overlapping and cumulative processes. The first one, examined in section 3.3, arises from the complementarity between the fragmentation of production and stricter intellectual property rights. The second, which we just discussed, results from the role of 
intangibles within the GVC form of industrial organization: firms playing a leading role in the integration benefit from natural monopoly forces arising from the complementarities between the participants to the chain, from the collection of data generated by the activities along the chains, and from the uneven distribution of returns to scale between tangible intensive and intangible intensive nodes.

These various intellectual monopoly forces are not exclusive from one another and generate rents that can be combined. Table 1 summarizes our argument by clarifying and illustrating these distinctive but corresponding rents. Legal monopoly rents arise from patents, copyrights and trademarks. They necessitate juridical enforcement that protects $R \& D$ and marketing expenses of their owners by artificially rationing the uses of the protected knowledge. Natural monopoly rents result from network externalities when the investment supporting the network exhibits return to scale and sunk costs, which is the case for information system and supply chain management know-how that allowed the deepening of integration in the past decades. We call dynamic innovation rents those benefits accruing from the ability to centralize the data. This centralization fosters a cumulative advantage in terms of ability to innovate that we identify with Schumpeter "Mark II" pattern of innovation of "creative accumulation" (Malerba \& Orsenigo, 1995). Finally, we label as intangibles-differential rent, the rent accruing from uneven distribution of intangible intensity and the resulting uneven cost dynamics. The name originates from differential land rent Ricardo identified to characterized the differential returns between unevenly fertile lands (Ricardo, 1817).

Table 1: Intellectual monopolies in GVCs: A taxonomy of rents related to intangible assets.

\begin{tabular}{|c|c|c|c|}
\hline TYPE & & DESCRIPTION & EXAMPLE \\
\hline \multicolumn{4}{|c|}{ LEGAL IP RENT } \\
\hline & $\begin{array}{l}\text { PATENTS, } \\
\text { COPYRIGHTS, } \\
\text { TRADEMARKS }\end{array}$ & $\begin{array}{l}\text { Rationing via exclusive rights on product } \\
\text { production, process uses, cultural and } \\
\text { scientific items, and marketing } \\
\text { investment }\end{array}$ & $\begin{array}{l}\text { Patents on pharmaceuticals, } \\
\text { software features and coding, } \\
\text { names protection (Nike, Louis } \\
\text { Vuitton) }\end{array}$ \\
\hline \multicolumn{4}{|c|}{ NATURAL MONOPOLY RENT } \\
\hline & $\begin{array}{l}\text { TOLL ON GVC } \\
\text { INTEGRATION }\end{array}$ & $\begin{array}{l}\text { Returns on intangibles underlying the } \\
\text { integration } \\
\text { Network complementarities within GVC } \\
\text { Sunk costs resulting from asset } \\
\text { specificities }\end{array}$ & $\begin{array}{l}\text { Apple supply chain } \\
\text { management } \\
\text { Valeo, Bosch supply chain } \\
\text { management of auto parts }\end{array}$ \\
\hline
\end{tabular}


SCHUMPETER

MARK II VIA DATA

COLLECTION
Centralization data generated along GVCs via asymmetric information systems

Data fuel Schumpeter Mark II innovation path
Siemens sensors on machinery, Goodyear tires sensors Wal-Mart retailink software Amazon shopping histories

\section{INTANGIBLES-DIFFERENTIAL RENT}

UNEVEN RETURNS Uneven returns to scale on intangibles TO SCALE vis-à-vis tangibles allow intangible intensive segments of the chain to capture a larger share of the gains
Apple and Nike fabless manufacturing versus assembling factories Nespresso versus coffee producers

\section{Intellectual monopoly, economic growth and development}

Industrial upgrading within GVCs has become, in some circles, synonymous with economic development. China's enormous industrialization success has prominently featured GVC participation. And other countries -- from Mexico to Poland to Vietnam and others -- have tried to utilize the market access and reduced entry barriers from GVC participation as development strategies. As GVCs become more IP-intensive, what will be the impact of intellectual monopoly on prospects for economic growth and development? We see three issues. One is the uneven geographical distribution of intangibles that may limit economic and social upgrading by developing countries. Second is that the monopolization dynamics may exacerbate trends in high-income economies concerning financialization and a slowdown of capital investment. Finally, the capture of value via control over intangibles can be linked to the erosion of national tax bases, an issue that concerns developing and high-income economies alike.

\subsection{Uneven geographical distribution of intangibles}

There is a highly skewed distribution of intangible-intensive and non-intangibleintensive firms across the world, with the former heavily concentrated in industrialized countries. Figure 13 shows the mean and the median of industry-country intangibleasset intensity for advanced economies and the rest of the world. This ratio of intangible to tangible assets increased significantly for both groups since 2000; however, there is a huge gap between them, and this gap grew larger in favor of advanced economies. Note that the mean is well above the median in both cases, indicating a concentration of intangible asset intensity in a small number of firms. At the lower level of relative intangible-asset intensity in the rest of the world, this deviation of mean from median 
suggests that most of these country's industries are almost completely deprived from control over intangible assets.

Figure 13: Relative intangible asset intensity in advanced and developing countries, (2000-2015) ${ }^{4}$

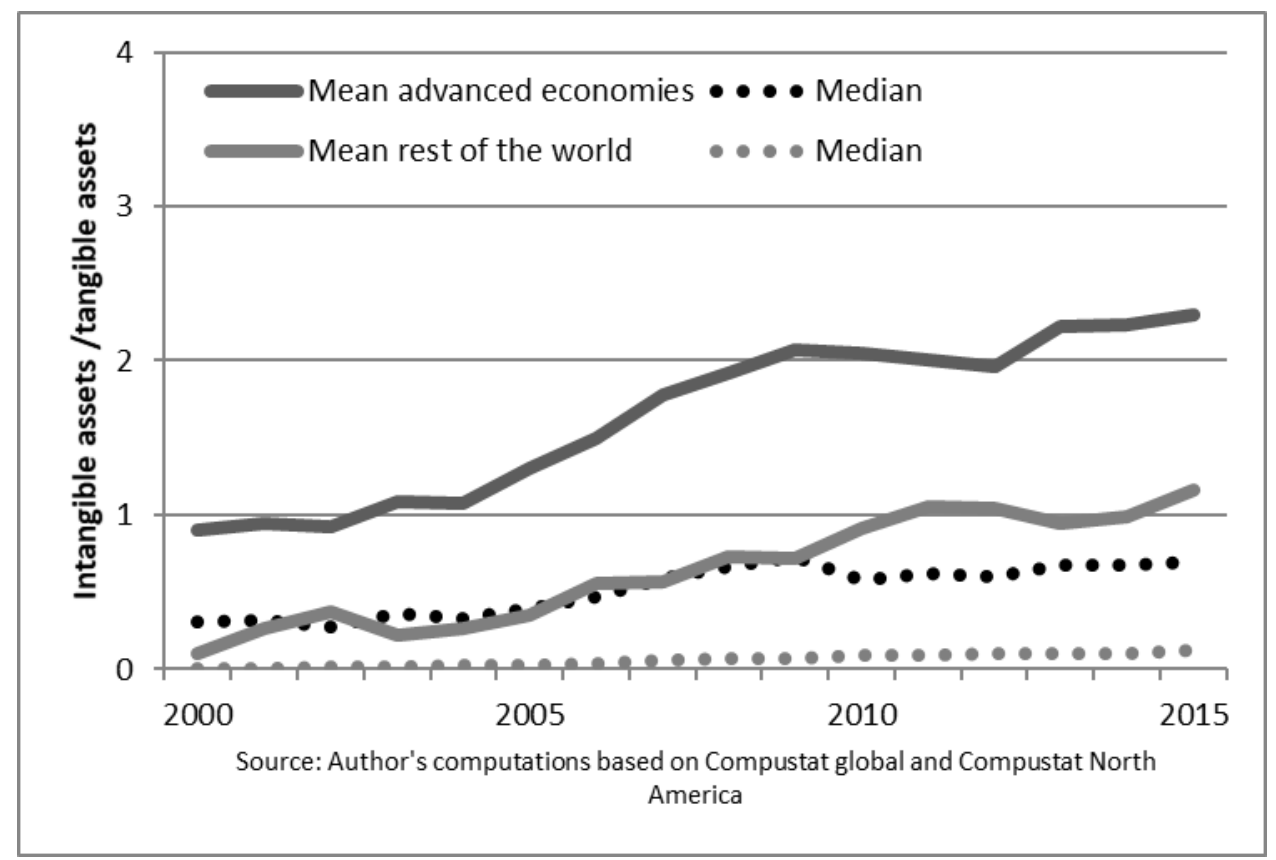

The skewed distribution of intangible assets limits value capture opportunities by tangible-intensive producers from the south and let not much room for social upgrading. An example is the coffee GVC, which is largely buyer driven and dominated by a relatively small number of multinational companies headquartered in the large coffeeconsuming countries (WIP0, 2017, pp. 12-13). Patent data suggest that the most innovative value chain stages are those closer to the consumer, including the modern espresso machines and coffee capsules. As a result, direct intellectual property barriers and indirect barriers arising from branding, protecting the access to final consumers, combine to erect powerful entry barriers for Southern producers to the final market. Modern marketing techniques allowing the collection of consumer data play an additional role in preventing producers to climb the value chain, while the uneven distribution of intangibles allow lead firms to reap a disproportionate share of the benefits of output expansion.

4 Average and median industry/country by country group based on revenue weighted average obervations (a particular firm in a particular year, weighted by the revenue of that year for that firm). All sectors except ISIC A, B, K and 0 : agriculture, mining and carrying, financial and insurance activities and public administration. IMF Advanced countries versus the rest of the world. Top 1\% eliminated, only positive values observations. Intangible intensity: intangible / tangible assets (Tangible assets as Property, Plant, and Equipment (Net Total) (PPENT)). In 2000, information is available for 385 industry/country in advanced economies and 113 in developing countries ; on 2015, these occurrence are respectively 660 and 368. 
While, this example is likely relevant in a number of industries and countries, the case of China is particular. Because of the size of its domestic market and high degree of political centralization, it has been able to resist IP protections for some time and to capture some knowledge circulating in GVCs to enhance domestic development. Most developing countries are not in a position to do this.

\subsection{Financialization and stagnation tendencies with intellectual monopoly}

A second concern that arises from our analysis of intellectual monopoly in GVCs is financialization, understood as the disconnection between profits and investment (for a review see. US firms in particular have had high levels of profit and cash flow in the past 15 to 20 years associated with a disproportionately large payout to shareholders in the form of dividends and share buybacks and sluggish investment (Gruber \& Kamin, 2015; Gutiérrez \& Philippon, 2016; Lee, Shin, \& Stulz, 2016). This dimension of financialization has been linked in the US to GVC participation to the extent that large oligopoly firms manage to expand their profits as they capture value through cheaper imports (Auvray \& Rabinovich, 2017; W. Milberg \& Winkler, 2009; William Milberg, 2008). Our emphasis on intellectual monopoly pushes the argument one step further: monopoly rents arising in GVCs from IPRs and the capture of network externalities enhance market power of lead firms also encourage financialization and put a drag on investment.

Monopolistic tendencies have long been linked to lower social welfare and declining economic growth (Baran \& Sweezy, 1966; Shapiro, 1988; Steindl, 1952). As they acquire market power through concentration, oligopolistic firms seek to avoid the danger and the cost of waging an uncertain competitive war and prefer instead to informally coordinate their prices with their main competitors. The result is price rigidity and an adjustment to market conditions through capacity utilization. High profits and low investment go hand-in-hand. In the case of intellectual monopolization in GVCs there are two main avenues for some monopoly-stagnation dynamics. The first is the dearth of investment opportunities arising from IPRs (Pagano, 2014; Pagano \& Rossi, 2009). The second is the endogenous monopoly dynamics resulting from intangibles circulation in GVCs. Market power means limited competitive pressure on lead firms, so that these firms are less compelled to invest. As the same time, current high rates of return act as a hurdle rate, limiting the opportunities for investment by potential rivals. Together, these two mechanisms can contribute to low reinvested earnings and higher financial payout, resuting in a lower rate of economic growth and higher inequality of income and wealth.

\subsection{Intangible assets and tax avoidance in GVCs}

Another related issue concerns the weakening of national tax bases. At the beginning of the 2010s, source indicate that profit shifting was costing the U.S. government between $\$ 77$ and $\$ 130$ billion annually in corporate tax revenue. These revenue losses have increased significantly over time since close to $40 \%$ of multinational profits are shifted to low-tax countries each year (Clausing, 2016; Tørsløv, Wier, \& Zucman, 2018; Zucman, 
2015). The lack of harmonization of tax structures among countries provides opportunities to arbitrage tax regimes via transfer prices, countertrade, and multichannel remittance. Information systems used by transnational corporations to manage GVCs can incorporate this information and automatically adjust the flow and transfer prices accordingly (Prasad \& Sounderpandian, 2003, p. 243). In this way, GVC trade may "hide, obscure and relocate wealth to the extent that they break loose from the location of value creation and heighten inequality" (Seabrooke \& Wigan, 2017, p. 257). Intangibles are almost free from any constraint of localization, allowing lead firms to fully exploit fiscal opportunities and nurture "Global Inequality Chains" (Quentin \& Campling, 2018). For example, Apple transfers intellectual property, sales rights and licensing rights to low tax jurisdictions, such as Ireland, and exploits international regulatory loopholes. This allows the corporation to accumulate profit there and shield foreign income from tax payment, as the firm diminishes it US profits by registering $60 \%$ (by 2011) of its R\&D expenses in these low tax jurisdictions (Wildauer \& Lopez Bernardo, 2017).

Despite the intensifying discussion in international circles on the issue of tax avoidance, research by the Financial Times shows that the effective taxation of multinational profits fell in absolute terms by two percentage points in the decade from 2008 (Toplensky, 2018). Rate cuts and the spreading of patent boxes that gives tax breaks for IP have fueled tax competition among countries.

\section{Conclusion}

Markets for intellectual property have become increasingly subject to monopoly power in the past 10-15 years. We have shown that this has both contributed to the expansion of GVCs and at the same time to rising inequality of income distribution across and within countries as a result of expanded trade in tasks. The tails of the smile curve reflecting the international division of labor have steepened because of the monopoly power of those controlling IP both for IP products and for the non-fabrication and nonassemby portions of the value chain in traditional tangible goods. The barrier to entry from intellectual monopoly further depresses the value of fabrication and assembly by adding to global output capacity.

The overall consequences of increasing GVC trade and stricter IPRs within GVCS for developing countries are nonetheless ambiguous: on the one hand, IP protection contributes to a higher return on the control of intangible assets within GVCs, increasing developing countries' opportunities for economic upgrading; on the other hand, this comes at a high price as wider and stronger intellectual monopoly rights imply greater restriction on the scope of knowledge appropriation by developing countries, impose entry barriers to some market segments and spawn rising IP payments. 
The presence of network dynamics and scale economies give intellectual monopoly today an entirely new significance compared to the the traditional world of intellectual property. And intellectual monopoly, we have argued is central to the life and dynamic of GVCs. GVCs exhibit networks externalities arising from complementarities between participants. These externalities lead to a highly uneven distribution of gains because of (1) the gate-keeper position of the integrator, (2) the firm's ability to capture and benefit from the bulk of data generated by the software infrastructure that supports the integration and (3) the uneven distribution of returns to scale depending on a variation in the degree of intangible-asset intensity across firms in any chain.

Policy implications of the analysis are beyond the scope of this paper. Intellectual monopoly may require a regulatory response, as there may be considerable social benefit from weaker IPRs and data openness. The appropriate policy response to the issues of complementarity and scalability of intangibles in GVCs requires further analysis, but it is evident that there is a need to take into account network externalities because they entail a distinctive process of knowledge monopolization compared to the traditional IP regulatory rationale.

\section{References}

Aguiar de Medeiros, C., \& Trebat, N. (2017). Inequality and Income Distribution in Global Value Chains. Journal of Economic Issues, 51(2), 401-408.

Akhtar, S., \& Ferguson, I. (2011). Intellectual Property Rights and International Trade (CSR Report for Congress No. RL34292). Washington DC. Retrieved from https://www.hsdl.org/?view\&did=730709

Aronow, S., Ennis, K., \& Romano, J. (2017). The Gartner Supply Chain Top 25 for 2017 (No. 13). Gartner consulting. Retrieved from https://www.gartner.com/doc/3728317/gartnersupply-chain-top-

Auvray, T., \& Rabinovich, J. (2017). The financialisation-offshoring nexus and the capital accumulation of US nonfinancial firms, (hal-01492373, version 1). Retrieved from https://hal.archives-ouvertes.fr/hal-01492373/

Baldwin, R. E. (2016). The great convergence: information technology and the new globalization. Cambridge, Massachusetts: The Belknap Press of Harvard University Press.

Baran, P. A., \& Sweezy, P. M. (1966). Monopoly capital: An essay on the American economic and social order (Vol. 73). NYU Press.

Barlett, D. L., \& Steele, J. B. (2011, November 20). Apple's American job disaster - Philly. Retrieved March 13, 2018, from http://www.philly.com/philly/opinion/20111120_Apple_s_American_job_disaster.html

Barrett, B. (2017, April 3). Apple's Making Its Own GPU to Control Its Own Destiny. Retrieved March 9, 2018, from https://www.wired.com/2017/04/apples-making-gpu-controldestiny/

Baud, C., \& Durand, C. (2012). Financialization, globalization and the making of profits by leading retailers. Socio-Economic Review, 10(2), 241-266.

Bernard, A. B., \& Fort, T. C. (2015). Factoryless goods producing firms. American Economic Review, 105(5), 518-523. 
Blair, D., Huntsman, J., Barrett, C., Lynn, W., Gorton, S., Wince-Smith, D., \& Young, M. (2017). update to the ip commission report. The Commission on the Theft of American Intellectual Property by The National Bureau of Asian Research.

Bouygues Construction. $(2017,11)$. Presse Release: Bouygues Construction teams with Dassault Systèmes and Accenture. Retrieved March 12, 2018, from http://www.bouygues-construction.com/en/press/release/bouygues-constructionteams-dassault-systemes-and-accenture

Boyd, W. (2013). Public Utility and the Low-Carbon Future. UCLA L. Rev., 61, 1614.

Bradshaw, T. (2017, April 7). The blessing and curse of being an Apple supplier. Retrieved March 9, 2018, from https://www.ft.com/content/3d49b76a-1b76-11e7-a266$12672483791 \mathrm{a}$

CAFTA. (2004, August 5). Final Text. Retrieved March 2, 2018, from /trade-agreements/freetrade-agreements/cafta-dr-dominican-republic-central-america-fta/final-text

Caputo, M., \& Zirpoli, F. (2002). Supplier involvement in automotive component design: outsourcing strategies and supply chain management. International Journal of Technology Management, 23(1-3), 129-159.

Chen, W. (2017). Do stronger intellectual property rights lead to more R\&D-intensive imports? The Journal of International Trade \& Economic Development, 1-19.

Chopra, S., \& Sodhi, M. S. (2004). Managing risk to avoid supply-chain breakdown. MIT Sloan Management Review, 46(1), 53.

Christopher, M. (2000). The agile supply chain: competing in volatile markets. Industrial Marketing Management, 29(1), 37-44.

Clausing, K. (2016). The Effect of Profit Shifting on the Corporate Tax Base in the United States and Beyond. National Tax Journal, 69(4), 905-934.

Daly, A. (2017). Beyond Hipster Antitrustt: A Critical Perspective on the European Commissionns Google Decision. SSRN Electronic Journal.

eMarketer. (2017, September 21). Google and Facebook Tighten Grip on US Digital Ad Market. Retrieved March 15, 2018, from https://www.emarketer.com/Article/Google-FacebookTighten-Grip-on-US-Digital-Ad-Market/1016494

Foley, D. K. (2013). Rethinking Financial Capitalism and the "information" Economy. Review of Radical Political Economics, 45(3), 257-268.

Gereffi, G. (2014). Global value chains in a post-Washington Consensus world. Review of International Political Economy, 21(1), 9-37.

Gereffi, G., Humphrey, J., \& Sturgeon, T. (2005). The governance of global value chains. Review of International Political Economy, 12(1), 78-104.

Gibbon, P. (2008). Governance, entry barriers, upgrading: A re-interpretation of some GVC concepts from the experience of African clothing exports. Competition \& Change, 12(1), 29-48.

Gillai, B., Rammohan, S. V., \& Lee, H. L. (2014). Similarities in Managing Supply Chain Sustainability and Intellectual Property.

Gruber, J. W., \& Kamin, S. B. (2015). The corporate saving glut in the aftermath of the global financial crisis.

Guo, S. (2016). A Story of Convergence of IPR Regimes: The IPR Chapter in the China-Korea Free Trade Agreement. The Chinese Journal of Global Governance, 2(2), 164-194.

Gutiérrez, G., \& Philippon, T. (2016). Investment-less Growth: An Empirical Investigation. 
National Bureau of Economic Research.

Hanel, P. (2006). Intellectual property rights business management practices: A survey of the literature. Technovation, 26(8), 895-931.

Haskel, J., \& Westlake, S. (2018). Capitalism without capital: the rise of the intangible economy. Princeton Oxford: Princeton University Press.

Haucap, J., \& Heimeshoff, U. (2014). Google, Facebook, Amazon, eBay: Is the Internet driving competition or market monopolization? International Economics and Economic Policy, 11(1-2), 49-61.

Hermann, M., Pentek, T., \& Otto, B. (2016). Design principles for industrie 4.0 scenarios (pp. 3928-3937). Presented at the System Sciences (HICSS), 2016 49th Hawaii International Conference on, IEEE.

Hertz, A. Z. (1997). Shaping the Trident: Intellectual Property Under NAFTA, Investment Protection Agreements and at the World Trade Organization. Can.-USLJ, 23, 261.

Ho, C. (2015). Sovereignty Under Siege: Corporate Challenges to Domestic Intellectual Property Decisions. Berkeley Tech. LJ, 30, 213.

Ho, C. (2016). A Collision Course Between TRIPS Flexibilities and Investor-State Proceedings.

Humphrey, J. (2003). Globalization and supply chain networks: the auto industry in Brazil and India. Global Networks, 3(2), 121-141.

Kaeser, J., \& Gross, D. (2016, February 9). Siemens CEO Joe Kaeser on the Next Industrial Revolution. Strategy and Business. Retrieved from https://www.strategybusiness.com/article/Siemens-CEO-Joe-Kaeser-on-the-Next-IndustrialRevolution?gko=efd41

Kasolowsky, B., \& Leikin, E. (2017). Eli Lilly v. Canada: A Patently Clear-Cut Dismissal on the Facts, but Opening the Door for Future Claimants on the Law. Journal of International Arbitration, 34(5), 889-900.

Kennedy, M. (2016). WTO Dispute Settlement and the TRIPS Agreement (Vol. 24). Cambridge University Press.

Khan, L. M. (2016). Amazon's antitrust paradox. Yale LJ, 126, 710.

Lee, D., Shin, H., \& Stulz, R. M. (2016). Why Does Capital No Longer Flow More to the Industries with the Best Growth Opportunities? National Bureau of Economic Research.

Leukert, B. (2017, September 18). Digitalization, Industry 4.0 and the Future of Industrial Production. Retrieved March 14, 2018, from https://blogs.sap.com/2017/09/18/digitalization-industry-4.0-and-the-future-ofindustrial-production/

Liberti, L. (2010). Intellectual Property Rights in International Investment Agreements (OECD Working Papers on International Investment No. 2010/01).

Ma, A. (2008, April 1). SIEMENS: customized and regional IP strategies --- China Intellectual Property. Retrieved March 8, 2018, from http://www.chinaipmagazine.com/en/journalshow.asp?id=285

Malerba, F., \& Orsenigo, L. (1995). Schumpeterian patterns of innovation. Cambridge Journal of Economics. https://doi.org/10.1093/oxfordjournals.cje.a035308

Mansfield, E. (1994). Intellectual property protection, foreign direct investment, and technology transfer (IFC Discussion paper No. 19). World Bank.

Marr, B. (2017, January 23). Really Big Data At Walmart: Real-Time Insights From Their 40+ Petabyte Data Cloud. Retrieved March 14, 2018, from 
https://www.forbes.com/sites/bernardmarr/2017/01/23/really-big-data-at-walmartreal-time-insights-from-their-40-petabyte-data-cloud/

Milberg, W., \& Winkler, D. (2009). Financialisation and the dynamics of offshoring in the USA. Cambridge Journal of Economics, 34(2), 275-293. https://doi.org/10.1093/cje/bep061

Milberg, William. (2008). Shifting sources and uses of profits: sustaining US financialization with global value chains. Economy and Society, 37(3), 420-451.

Molla, R. (2017, July 24). Google leads the world in digital and mobile ad revenue. Retrieved March 15, 2018, from https://www.recode.net/2017/7/24/16020330/google-digitalmobile-ad-revenue-world-leader-facebook-growth

Mosca, M. (2008). On the origins of the concept of natural monopoly: Economies of scale and competition. The European Journal of the History of Economic Thought, 15(2), 317-353.

Moser, P. (2013). Patents and Innovation: Evidence from Economic History. Journal of Economic Perspectives, 27(1), 23-44. https://doi.org/10.1257/jep.27.1.23

Nathan, D., \& Sarkar, S. (2011). A note on profits, rents and wages in global production networks. Economic and Political Weekly, 53-57.

Nordhaus, W. D. (2015). Are We Approaching an Economic Singularity? Information Technology and the Future of Economic Growth. National Bureau of Economic Research.

Oxley, J. E. (1997). Appropriability hazards and governance in strategic alliances: A transaction cost approach. The Journal of Law, Economics, and Organization, 13(2), 387-409.

Oxley, J. E. (1999). Institutional environment and the mechanisms of governance: the impact of intellectual property protection on the structure of inter-firm alliances. Journal of Economic Behavior \& Organization, 38(3), 283-309.

Pagano, U. (2014). The crisis of intellectual monopoly capitalism. Cambridge Journal of Economics, 38(6), 1409-1429.

Pagano, U., \& Rossi, M. A. (2009). The crash of the knowledge economy. Cambridge Journal of Economics, 33(4), 665-683.

Peng, M. W., Ahlstrom, D., Carraher, S. M., \& Shi, W. S. (2017). An institution-based view of global IPR History. Journal of International Business Studies, 48(7), 893-907.

Peoples, J., \& Sugden, R. (2000). 8 Divide and rule by transnational corporations. The Nature of the Transnational Firm, 174.

Ponte, S., \& Daviron, B. (2011). Creating and Controlling Symbolic value. The Cultural Wealth of Nations, 197.

Ponte Stefano. (2009). Governing through Quality: Conventions and Supply Relations in the Value Chain for South African Wine. Sociologia Ruralis, 49(3), 236-257.

Prasad, S., \& Sounderpandian, J. (2003). Factors influencing global supply chain efficiency: implications for information systems. Supply Chain Management: An International Journal, 8(3), 241-250.

Quentin, D., \& Campling, L. (2018). Global inequality chains: integrating mechanisms of value distribution into analyses of global production. Global Networks, 18(1), 33-56.

Ramioul, M., \& Van Hootegem, G. (2015). Relocation, the restructuring of the labour process and job quality. The Outsourcing Challenge, 91.

Reagan, R. Proclamation 5885 by the President of the United States (1988). Retrieved from https://www.gpo.gov/fdsys/pkg/STATUTE-102/pdf/STATUTE-102-Pg5086.pdf

Ricardo, D. (1817). On the Principles of Political Economy, and Taxation. J. Murray.

Rochet, J., \& Tirole, J. (2006). Two-sided markets: a progress report. The RAND Journal of 
Economics, 37(3), 645-667.

Rodrik, D. (2018). What Do Trade Agreements Really Do? National Bureau of Economic Research.

Safari, A. (2017). Worldwide venture capital, intellectual property rights, and innovation. Industrial and Corporate Change, 26(3), 485-515. https://doi.org/10.1093/icc/dtw035

Sanders, N. R. (2016). How to use big data to drive your supply chain. California Management Review, 58(3), 26-48.

Satariano, A., \& Burrows, P. (2011). Apple's supply-chain secret? Hoard lasers. Bloomberg Businessweek, 4, 50-54.

Schmidt, E., \& Cohen, J. (2014). The new digital age: reshaping the future of people, nations and business (1. publ. in paperback). London: Murray.

Seabrooke, L., \& Wigan, D. (2017). The governance of global wealth chains. Review of International Political Economy, 24(1), 1-29.

Sell, S. K. (2010). TRIPS was never enough: vertical forum shifting, FTAS, ACTA, and TPP. J. Intell. Prop. L., 18, 447.

Sell, S. K., \& Prakash, A. (2004). Using ideas strategically: The contest between business and NGO networks in intellectual property rights. International Studies Quarterly, 48(1), 143-175.

Shadlen, K. C. (2017). Coalitions and compliance: the political economy of pharmaceutical patents in Latin America (First Edition). Oxford, United Kingdom: Oxford University Press.

Shapiro, N. (1988). Market structure and economic growth: Steindl's contribution. Social Concept, 4, 72-83.

Shin, S., \& Eksioglu, B. (2014). Effects of RFID technology on efficiency and profitability in retail supply chains. Journal of Applied Business Research, 30(3), 633.

Staricco, J. I., \& Ponte, S. (2015). Quality regimes in agro-food industries: A regulation theory reading of Fair Trade wine in Argentina. Journal of Rural Studies, 38, 65-76.

Steindl, J. (1952). Maturity and Stagnation in American Capitalism. New-York: Monthly Review Press.

Stevens, G. C., \& Johnson, M. (2016). Integrating the supply chain... 25 years on. International Journal of Physical Distribution \& Logistics Management, 46(1), 19-42.

Tang, C., \& Tomlin, B. (2008). The power of flexibility for mitigating supply chain risks. International Journal of Production Economics, 116(1), 12-27.

Teece, D. J. (1986). Profiting from technological innovation: Implications for integration, collaboration, licensing and public policy. Research Policy, 15(6), 285-305.

Timmer, M. P., Erumban, A. A., Los, B., Stehrer, R., \& de Vries, G. J. (2014). Slicing up global value chains. Journal of Economic Perspectives, 28(2), 99-118.

Tirole, J. (2017). Economics for the common good. (S. Rendall, Trans.).

Tokatli, N. (2008). Global sourcing: insights from the global clothing industry-the case of Zara, a fast fashion retailer. Journal of Economic Geography, 8(1), 21-38.

Toplensky, R. (2018, March 11). Multinationals pay lower taxes than a decade ago. Retrieved March 17, 2018, from https://www.ft.com/content/2b356956-17fc-11e8-93764a6390addb44

Tørsløv, T., Wier, L., \& Zucman, G. (2018). The Missing Profits of Nations (No. w24701). Cambridge, MA: National Bureau of Economic Research.

US SEC. (2017). Alphabet Inc. Consolidated Statemnt of Income. Nine months ended September 
30, 2017. Retrieved March 15, 2018, from

https://www.sec.gov/Archives/edgar/data/1652044/000165204417000042/goog10qq32017.htm\#s26AAD44B6D2A899A0549C37D13E1E28E

USTR. (2017). 2017 Special 301 Report on Intellectual Property Rights. Washington DC. Retrieved from https://ustr.gov/sites/default/files/301/2017\%20Special\%20301\%20Report\%20FINA L.PDF

Villareal, M., \& Fergusson, I. F. (2017). The North American Free Trade Agreement (NAFTA). von Lewinski, S. (2016). The WTO/TRIPS Dispute Settlement Mechanism: Experiences and Perspectives. In TRIPS plus 20 (pp. 603-620). Springer.

Wang, J. (2006). Economies of IT systems at Wal-Mart-An historical perspective. Journal of Management Information and Decision Sciences, 9(1), 45.

Wildauer, R., \& Lopez Bernardo, J. (2017, November). The impact of profit shifting on national accounts: Revisiting US trade elasticities. Presented at the Forum for Macroeconomic and Macroeconomics Policy, 21st Annula Conference, Berlin.

Williamson, O. E. (2008). Outsourcing: Transaction cost economics and supply chain management. Journal of Supply Chain Management, 44(2), 5-16.

Wilson, M. (2015, May 6). Wal-Mart focuses on speed, innovation with SAP's HANA technology. Retrieved March 15, 2018, from https://www.chainstoreage.com/article/wal-martfocuses-speed-innovation-saps-hana-technology/

WIPO. (2017). Intangible Capital in Globhal Value Chains (World Intellectual Property Report). Genève: World Intellectual Property Organization.

WTO. (2010, April). DS362 - China - Measures Affecting the Protection and Enforcement of Intellectual Property Rights. Retrieved March 2, 2018, from https://www.wto.org/english/tratop_e/dispu_e/cases_e/ds362_e.htm

Wu, F., Li, H. Z., Chu, L. K., \& Sculli, D. (2013). Supplier selection for outsourcing from the perspective of protecting crucial product knowledge. International Journal of Production Research, 51(5), 1508-1519. https://doi.org/10.1080/00207543.2012.701769

Yu, P. K. (2017). When the Chinese Intellectual Property System Hits 35.

Zucman, G. (2015). The hidden wealth of nations: The scourge of tax havens. University of Chicago Press. 